\title{
ULUSLARARASI İ̧̧BIRLİ̆̈̇ PROJELERİ VE ORTA ASYA: BAĞIMSIZLIKLARI KORUYACAK GÜÇ DENGESİ İÇİN ARAYIŞLAR *
}

\author{
International Cooperation Projects and Central Asia: Seeking for a Balance of Power to Preserve Independence
}

\author{
Kalmira RYSKULOVA ${ }^{* *}$
}

$\ddot{O} z$

SSCB'nin dăğlması sonucu elde edilen egemen devlet statüsü, birlik cumhuriyetlerine iç ve dış egemenlik haklarını kazandırmanın yanı sıra bu hakları devam ettirme sorumluluğunu da beraberinde getirmiştir. Geçmişteki yönetim tarzı ile ona karş̧ gelen değerlerin harmanlanmasını gerektiren çok yönlü işbirliği, Orta Asya ülkeleri açısından söz konusu sorumluluğun yerine getirilmesini ve bölgeyi kendi etki alanına katmak isteyen güçler arasındaki dengeyi să̆layacak sayılı stratejilerden biriydi. Lakin söz konusu strateji yalnızca bölge ülkelerinin ihtiyaçları ile sınırlı olmayıp, dış güçlerin geniş çapl jeopolitik hedefleri ile de doğrudan bağlantılı olduğu için yapılan işbirliği projelerinde bölge dışı ilişkiler ă̆ırlık kazanmıştır. Iktisadi ve içtimai faktörler de göz ardı edilmemekle birlikte, bölgedeki çok yönlü işbirliğine sebep teşkil eden siyasi beklentiler bu çalışmanın ana konusunu oluşturmaktadır.

Devlet inşa süreci boyunca ülkelerin kalkınma firsatlarında meydana gelen farklılıklar ve bu kalkınmaya engel oluşturacağı endişesi yaratan ortak kaynaklar üzerindeki tartışmalar bölge devletlerini birbirinden uzaklaştırmıştır. İçerde artan bir mesafe söz konusuyken, Rusya 'nın bölgeyi yeniden kendi etki alanına alacağı endişesi, bölge ülkelerini Batı dünyası ve Çin ile işbirliğine yöneltmiş, Türkiye, Iran, Hindistan ve diğer eksen ülkeler olmak üzere bölgeye ilgi gösteren aktör sayısındaki artış da Orta Asya açısından işbirliği alanını gittikçe genişletmiştir.

Anahtar Kelimeler: Uluslararası İşbirliği, Güç Dengesi, Orta Asya, Siyasi Egemenlik, Bölgesel Entegrasyon.

\section{Abstract}

Obtaining the sovereign state status entitled the former USSR republics with the rights of independence along with the responsibility for preserving those rights. The multifaceted cooperation required blending of the management style of the past with the opposing ones was one of the few strategies in terms of Central Asian countries to preserve the sovereignty and to balance the powers desiring to bring the region into their own domain. However, since that strategy was directly linked to the broad geopolitical objectives of the external powers, extra-regional relations gained more importance. Therefore, the main topic of this study is the political expectations that lead to the multifaceted cooperation.

The differences in the development opportunities of countries and the controversies over the common sources concerned as an obstacle to development alienated the states in the region. The growing distance within the region and the concern that Russia would take it back to its domain of influence, led the countries in the region to cooperate with the Western world and China. In addition, the increase in the number of actors interested in the region, including Turkey, Iran, India and other axis countries, has widened the scope of cooperation in Central Asia.

Key Words: International Cooperation, Balance of Power, Central Asia, Political Sovereignty, Regional Integration.

\section{Giriş}

Sovyetler Birliği’nin dağılması sonucu elde edilen egemen devlet statüsü, birlik cumhuriyetlerine iç ve dış politikada bağımsız hareket etme hakkını kazandırmanın yanı sıra bu bağımsızlığı devam ettirme sorumluluğunu da beraberinde getirmiştir. Kazakistan, Kırgızistan, Özbekistan, Tacikistan ve Türkmenistan

\footnotetext{
* DOI: 10.34189/asyam.4.1.006

** Gazi Üniversitesi İIBF Uluslararası İlişkiler Bölümü mezunu, ryskulovakalmira@ gmail.com
} 
olmak üzere Orta Asya ülkeleri de söz konusu sorumluluğu yerine getirmede, mevcut şartlar ve uluslararası sistemin yapısı gereği, çeşitli devletlerarası işbirliği girişimlerinde bulunmuşlardır. Bu tür girişimlere sebep teşkil eden ekonomik, askeri ve sosyal faktörler de göz ardı edilmemekle birlikte, bölge ülkelerinin yer aldığ 1 işbirliği projelerine sebep olan siyasi beklentiler bu çalışmanın temel araştırma konusunu oluşturmaktadır.

Araştırmanın temel amacı, Orta Asya ülkelerinin kendi aralarında ve bölge dışı aktörler ile yaptıkları işbirliği projelerinde, ülke bağımsızlığını koruma ve dış politikada siyasi güç dengesi oluşturma yönündeki girişimlerini analiz etmektir.

Araştırma konusunun önemini belirleyen ilk unsur, Orta Asya bölgesinde meydana gelen işbirliği girişimlerinin, sadece Rusya, Çin, $\mathrm{ABD}, \mathrm{AB}$ ve diğer uluslararası aktörlerin, aralarındaki rekabetten kaynaklanan tek taraflı jeostratejik denge arayışının bir sonucu olmadığını, bu girişimlerde bölgenin kendi içerisindeki şartların ve bölge devletlerinin izledikleri güç dengesi arayışının da önemli rol oynadığını vurgulama amacıdır. Çünkü bölge içerisinde siyasi güç dengesi arama meselesinin tomurcuklanmış olması, dış güçlerin bölgeye yönelik stratejik denge arayışına girmeleri açısından önemli bir sebep teşkil etmiştir.

Konunun tercih edilmesindeki diğer bir unsur, Orta Asya devletleri ile dış güçler arasındaki işbirliği projelerinin daha çok ekonomi, güvenlik veya enerji sektörleri üzerinden ele alınmasıdır. Bu durumda siyasi sebepler işbirliğine taraf olan aktörler tarafindan açıkça dile getirilmemekte, üçüncü taraflarca yapılan yorumlarla sınırlı kalmaktadır. Her ne kadar yukarıda sözü edilen sektörler devlet siyasetinin belirlenmesinde önemli rol oynasalar da, ülkelerarası işbirliği girişimlerinin siyasi yönünü açıklamakta yetersiz kalmaktadırlar.

Konu ile ilgili üçüncü ve güncel bir unsur ise, Orta Asya ülkelerinin güç dengesi arayışında yönelebilecekleri aktör sayısının gittikçe artmasıdır. Bağımsızlıktan bugüne bölgede aktif olan Rusya, Çin ve Batı ( $\mathrm{ABD}$ ve $\mathrm{AB}$ ) ülkelerinin taraf oldukları projelerin sayısı, günümüzde Hindistan, Türkiye, Japonya ve İran başta olmak üzere diğer Orta Doğu devletlerinin de taraf olduğu projeler ile tamamlanmaktadır. Ticari, kültürel veya güvenlik ilişkileri adı altında varılan bu tür işbirliği girişimlerinin, Orta Asya ülkelerinin siyasi faaliyet alanını genişlettiği bir gerçektir.

Çalışmanın temeli, 'birçok bölgesel entegrasyon girişimleri, üye devletlerin, egemenlik haklarından ödün vermelerinin bir neticesi iken, Orta Asya topraklarında meydana gelen entegrasyon hareketlerinde, bölge ülkelerinin egemenliklerini koruma amacının önemli bir sebep teşkil ettiği' tezine dayanmaktadır.

Bu bağlamda öne sürülecek hipotezlerin bazıları aşağıdaki gibidir:

Bağımsızlık sonrası Orta Asya ülkeleri, ülke egemenliğini pekiştirme işlemleri ile ülkelerarası entegrasyon ilişkilerini aynı zamanda yürütmek zorunda kalmışlardır. Bu durumda, kendi aralarında entegrasyon oluşturmanın yanı sıra, birden fazla büyük güç ile işbirliği içine girmek, bölge devletleri tarafından egemenliği pekiştirmenin bir yolu olarak tercih edilmiştir.

Her ne kadar rejim güvenliği konusunda birbirlerini destekler gibi görünseler de, sahip oldukları kalkınma kapasiteleri ve avantajları arasındaki farklılıklar ve bölgesel sorunların çözümü ile ilgili görüş ayrılığı, ülkelerin bağımsızlıkları 'Orta Asya Entegrasyonu' çerçevesinde değil de, dış güçler arasında gelip gitme şeklinde muhafaza etmelerine neden olmaktadır.

Bölgede yer alan işbirliği projelerinin değerlendirilmesi sürecinde, Orta Asya sınırları içerisinde meydana gelen entegrasyon hareketlerinin yanı sıra, Bağımsız Devletler Topluluğu, Şanghay İşbirliği Örgütü, TÜRKSOY Uluslararası Türk Kültürü Teşkilatı, TÜRKPA, Büyük Orta Asya Projesi ve Avrasya Birliği'ne yönelik projelere ayrıntılı değinilecektir. Orta Asya ülkelerinin taraf olduğu entegrasyon ve işbirliği girişimlerinin siyasi boyutunu anlamak açısından, öncelikle Avrupa, Latin Amerika ve Güney Afrika bölgelerinde meydana gelen bütünleşme projeleri ile ilgili kuramsal ve uygulamalı değerlendirme yapilacaktır.

Çalışmanın teorik boyutu, klasik realizm ve neorealizm, güç dengesi kuramı, fonksiyonalizm ve neofonksiyonalizm kuramlarının, devletlerarası bütünleşme ve işbirliği girişimleri konusunda öne sürdüğü yaklaşımlar aracılığıyla açıklanacaktır. 


\section{Entegrasyon ve İşbirliği Girişimlerinin Siyasi Sebepleri}

\subsection{Kuramsal Bakış}

Entegrasyon veya işbirliği girişimlerine yol açan temel argüman, güçlü devletlerin diğer bir gücü dengeleme ve zayıf devletlerin de güçlü olana karşı bağımsızlıklarını koruma maksatlarına dayandırılmaktadır. Özellikle diplomatik ve askeri yardımlaşma üzerine inşa edilen bu tür girişimler bazen resmi antlaşmalar ile teyit edilirken bazen resmi dayanağ kadar ülke bağımsızlığını sınırlayıcı olarak nitelendirilse de realist yaklaşımın tanımladığı çıkarcı aktörler tarafından oluşturulduğuna göre işbirliği projelerinin söz konusu aktörlerin belli başlı çıkarlarını karşıladığı da aşikârdır.

İşbirliği projelerinin taraf devletlere yönelik doğurduğu etkiler söz konusu projenin işlevsel niteliğine ve işbirliği düzeyine göre değişim göstermektedir. Bu bakımdan projeler 'işbirliğì' (cooperation), entegrasyon, ortaklık (partnership), ittifak (alliance) veya koalisyon olmak üzere çeşitli çatılar altında yürütülmektedir. ${ }^{1}$ Lakin burada belirtilmesi gereken husus, tüm bu proje çeşitlerinin kuramsal açıdan farklı tanımlarla birbirinden ayırt edilmiş olmasına rağmen, uygulamada gerek yetki, gerekse konu bakımından karma nitelikteki projelere daha sık rastlanıldığıdır.

Uluslararası işbirliğinin siyasi ağırlıklı sebeplerinin başında devletlerin "ideolojik dayanışma" adına bir araya geldikleri varsayımı yer almaktadır (Walt, 1985, ss. 19-20). Morgenthau tarafından öne sürülen bu varsayıma göre iki veya daha fazla olmak üzere devletlerin ideolojik yapısı ne kadar yakın ise bu devletlerin tek bir ittifak çatısı altında birleşme ihtimali de o kadar yüksektir. İngiliz siyaset uzmanı Viscount Palmerston bu varsayımı en iyi açıklayanlardan biridir. Ona göre benzer ideolojik yapıya sahip devletler arasında varılan işbirliği, taraf devletlerin kendi siyasi ilkelerini savunmalarını mümkün kılan en iyi stratejidir. Ülkedeki siyasi sistemin ilgili ülke açısından uygulanabilecek en iyi sistem olduğu ile ilgili algı yaratmak ve bu algının başka ülkeler tarafından da desteklendiğine inanmak devlet adamlarına siyasi özgüven kazandıracaktır.

İdeolojik dayanışma temelli işbirliğinin ikinci bir sebebi de benzer özelliklere sahip devletlerin birbirlerine karşı tehdit oluşturmayacağ 1 algısıdır. Bu durum aynı zamanda geniş ve popüler bir hareketin parçası kabul edilmekle işbirliği içerisindeki zayıf bir rejimin kendi meşruluğunu devam ettirmesine de kolaylık sağlamaktadır. Son olarak Marksizm-Leninizm örneğinde de görüldüğü gibi ideolojik benzerlik doğal olarak kendisiyle birlikte siyasi işbirliğini getirmektedir (Walt, 1985).

Devlet içerisindeki siyasi sistemin başka bir devlet tarafindan örtülü veya dolaylı yollardan manipüle edilmesi anlamına gelen siyasi nüfuz olgusu ise devletler arasında siyasi işbirliğini tetikleyen faktörlerden bir diğeridir. Siyasi nüfuzun bir neticesi olarak işbirliği, farklı dış aktörlere karşı sadakat besleyen devlet adamlarının, mevkilerini söz konusu devletlerle yakınlaşma yönünde kullanmaları, lobicilik ve diğer sivil toplum kuruluşları aracılığıyla siyasi kararların herhangi bir işbirliği projesinden yana değiştirilmesi, yurtdışı propagandanın yerel elit ve kamuoyu algılarını etkilemek üzere kullanılması yoluyla gerçekleştirilmektedir. Siyasi nüfuz olgusunun en önemli araçlarından biri de dış yardımdır. Dış yardım, bir araç olmanın yanı sıra başlı başına bir işbirliği sebebi olarak da değerlendirilebilmektedir. Zira 'yardım miktarı ne kadar çok ise, alıcı üzerindeki kontrol de o kadar büyüktür' algısı dış yardımı uluslararası işbirliğinin en etkin unsuru haline getirmektedir (Walt, ss. 30-31).

Devletlerarası işbirliğini temsil eden başarılı örneklerden bir diğeri de bölgesel entegrasyon projeleridir. Bölgesel işbirliğinin tarihsel sebeplerinin başında 'egemenliği yönetme' ilkesi gelmektedir. Söz konusu ilke gereği devletler ilk önce kendi aralarında, sonra geçmişteki sömürgeci aktörler ve genelde rakip ülkeler olmak üzere diğer uluslararası aktörler ile entegre olmaktadırlar. Bu süreç devletlerin uluslararası kimliklerini pekiştirme süreci veya onların uluslararası ilişkilere katılımını sağlayacak 'aktörlük' statüsü kazanma süreci olarak özetlenmektedir. 'Karşılıklı bağımlılığın yönetimi' ilkesi ise bölgesel entegrasyonun ikinci sebebini oluşturmakta, güvenlik, barış, sosyal ve ekonomik işbirliği gibi konularda ortak norm ve

\footnotetext{
${ }^{1}$ Proje çeşitlerinin siyasi tanımları için bakınız: BEST, Edward and Thomas Christiansen, (2014). "Regionalism in International Affairs", In John Baylis, Steve Smith, and Patricia Owens (Eds.), The Globalization of World Politics: An Introduction to International Relations, (Sixth edition), UK: Oxford University Press, 401- 417. Kajsa Ji Noe Oest, "The End of Alliance Theory", Institut for Statskundskab, c. 9, (March, 2007).
} 
davranışlara yol açarak devletlerin sosyalleşmesini sağlamaktadır. Son olarak 'uluslararasılaşma sürecinin yönetimi' aşaması, bölgesel kurumlar ile dünyadaki diğer aktörler arasındaki işbirliğini amaçlamaktadır. Bölgesel işbirliği bu aşamaya geldiğinde, ittifakların siyasi ve stratejik boyutu ağırlık kazanmakta, devletler bağımsızlıklarını çok yönlü koruma firsatını elde etmektedirler (Best ve Christiansen, 2014, s. 403).

Ayrıca evrensel düzeyde veya bölgesel düzeyde olsun uluslararası işbirliği projeleri taraf ülkelerin iç işlerini de derinden etkilemekle iç siyasetten kaynaklanan sebeplerin de bir sonucu olagelmektedir. Fonksiyonalistlerin de belirttiği gibi, proje çerçevesinde uygulanan ilke ve normlar, karar alma süreci ve diğer ortak kurallar, taraf devletlerin iç politikasını yapılandırmakta, hükümetler arasında güvenli bilgi alış verişini geliştirmektedir. Bu durum aynı zamanda yerel aktörlerin uluslararası rejime dâhil olmasını sağlayarak hükümetlerin söz konusu aktörler üzerindeki denetimini etkinleştirmekte, ikisi arasında karşıllklı dayanışmayı arttırmaktadır. Bu yolda hükümet başkanları ulusal çıkarlarını uluslararası ortama çıartabilmekte, dolayısıyla ülke içi egemenliğin meşruluk temelini de sağlamlaştırabilmektedirler (Moravcsik, 1994).

Bahsi geçen siyasi sebeplerin tümü tek bir işbirliği projesinde yer alamadığı gibi, taraf devletlerin her birinin bu sebeplere istinaden işbirliğine katıldığg da söylenemez. Üye devletlerin tarihi geçmişi, egemenlik kaynağı, ülkedeki siyasi iradenin yapısı ve nihayet jeostratejik konumdan kaynaklanan jeopolitik ihtiyaçlar devletlerarası işbirliğinin siyasi sebeplerinde ciddi farklılıkları ortaya koymaktadır. Bu bölümde sırasıyla sözü edilen politik sebepler her ne kadar kuramsal veya deneysel yöntemlerle tespit edilmiş olsa da, mevzubahis okumalarda devletlerin içyapısındaki farklılıkların ve sadece ilgili devlete has özelliklerin göz ard1 edildiği bir gerçektir.

\subsection{Avrupa, Latin Amerika ve Güney Afrika Bölgeleri Üzerinden Uygulamalı Değerlendirme}

Kuramsal alt yapısıyla uygulamalı boyutu arasında sistematik bir bağı olan ve bu özelliğiyle bölgesel işbirliği açısından bir örnek haline gelen $\mathrm{AB}$ ile buna müteakip oluşan diğer bölgesel işbirliği projelerindeki ortak amaç, ülkelerin eşit güç edinme imkanlarının olmadığı realist bir sistemde var olan güçleri birleştirmek, bağımsızlığı devam ettirmektir. Bölgeselleşmeye ilk örnek olarak Avrupa ülkelerinin birleşme amacı da Doğu Avrupa'da ilerleyen Sovyetler Birliği'ne karşı bir araya gelmekle beraber bölgedeki ABD hegemonyasını dengelemekti. Lakin Soğuk Savaş'ın yol açtığı iki kutuplu sistem Avrupa ülkelerine SSCB ile ABD'yi aynı anda dengeleme imkanı vermemiş, Birlik ABD'nin SSCB'yi dengeleme aracına dönüşmüştür.

Soğuk Savaş'ın sona ermesiyle Avrupa devletleri, aralarındaki birliği yeniden ABD'yi dengeleyici birleşme olarak görmeye başlamışlardır. Kendi bağımsızlı̆̆ı açısından tehlikeli olarak gördüğü gücü dengelemeye çalışırken $\mathrm{AB}$, bütünleşmiş ve genişlemiş bir aktör olarak uluslararası sistemdeki güç dengesinin yapısına da katkıda bulunmuş, dengelenmesi gereken bir güç konumuna gelmiştir. Eski sömürgeci devletlerden oluşan bir güç olarak $A B$ 'yi dengeleme arayışı bu sefer Latin Amerika ve Güney Afrika bölgelerindeki işbirliği projelerinde görülmeye başlamıştır. Lakin, sömürgeciliğin etkisinden henüz kurtulamamış olan bu bölgelerdeki birleşim, ticari, ekonomik alanlardaki projelerle sınırlı kalmıştır.

Latin Amerika ile Güney Afrika'daki denge arayışı, tarihi birtakım farklılıklara rağmen eski Sovyet ülkelerinin Rusya'yı dengeleme girişimlerine benzemektedir. Ülkelerin egemenliklerine kavuşur kavuşmaz bölgesel bir yapı altında birleşme çabaları, bu birleşimi jeopolitik firsatlara çevirmek isteyen dış güçlerin $\mathrm{ABD}, \mathrm{AB}$ ve Rusya gibi geçmişte bu topraklara nüfuz etmiş devletlerden oluşması ve nihayet bölge içerisinde meydana gelen ulusal çıkar ve siyasi rejim farklılı̆̆ından kaynaklanan uyuşmazlıklar söz konusu bölgelerdeki denge arayışlarının benzer yönlerini ortaya koymaktadır.

Mevzubahis işbirliği projelerinin siyasi ağırlıklı sebeplerinden bir diğeri ise, Morgenthau tarafından öne sürülen "ideolojik dayanışma" varsayımına dayandırılabilmektedir. Gerçekte de demokratik değerlerin Avrupa ülkelerini bir araya getirdiği gibi, Latin Amerika'da meydana gelen komünist ve sosyalist rejimler bölgede ABD etkisini dengeleyecek ortaklıklara yol açarken, apartheid karşıtı hareketler, Güney Afrika ülkelerinin eski sömürgeci güçleri dengeleyecek girişimlerine zemin hazırlamıştır.

İdeolojik dayanışma temelli işbirliğinin ikinci bir sebebi de benzer özelliklere sahip devletlerin birbirlerine karşı tehdit oluşturmayacağı algısıdır. Buna misal, genellikle AB ülkeleri açısından öne sürülen ve demokratik devletlerin birbirleriyle savaşa girmeyecekleri varsayımına dayanan "demokratik barış" 
yaklaşımıdır. Lakin, Avrupa ülkelerini bir arada tutan böyle bir yaklaşım, dış dünyada büyük bir destek görürken, örneğin Latin Amerika ülkeleri arasında varılan ve devletlerin hukuki eşitliği, iç işlere karışmama ve koşulsuz işbirliği ilkelerinin yer aldığ demokratik uzlaşmaya dayalı işbirliği girişimleri, birtakım eleştiri ve engellere maruz kalmıştır. Zira, Avrupa'da meydana gelen demokratik barış, AB-ABD işbirliğine yol açarken, Latin Amerika'da planlanan projelerde, AB-ABD işbirliğini dengeleme amacı ağır basmıştır.

Son olarak, sözü edilen bölgesel entegrasyon girişimlerinin işlevsel boyutuna bakmak gerekirse, AB dışında gelişen projelerin fonksiyonalizmin öne sürdüğ̈̈ 'seçmeli işbirliği' ${ }^{2}$ modeline dair olduklarını söylemek mümkündür. Üye devletlerin ortak refah uğruna imza attıkları 'kapsamlı işbirliği'ni temsil eden AB modelinden farklı olarak Latin Amerika ve Güney Afrika'da meydana gelen projeler, iktisadi veya içtimai alanların ağır bastığı seçmeli işbirliğine dayanmaktadırlar. Ayrıca, geçmişte kolonyal yönetime tabi olan ülkeler arasında varılan seçmeli projele modellerini, belli bir alanda başlayıp ilgili alandaki diğer sektörleri de ortak faaliyetlere teşvik eden spill-over yayılma stratejisiyle de açıklamak mümkündür. Örneğin, Latin Amerika'da birbirini izleyen CARICOM, CARIFTA, LAFTA ve MERCOSUR gibi ticariekonomik projeleri veya ticari entegrasyon girişimlerinin yanı sıra siyasi ve güvenlik alanlarındaki işbirliği planlarının da yer aldığı Güney Afrika Kalkınma Topluluğu ülkeler arası ilişkilerdeki spill-over etkisini ortaya koymaktadır.

\section{Orta Asya'da İşbirliği Projeleri ve Siyasi Bağımsızlığı Pekiştirme Arayışları}

Rejim güvenliği ve mevcut rejimi sürdürülebilir kılacak bir siyasi bağımsızlık, Orta Asya ülkelerinin yer alacă̆ 1 bölgesel entegrasyon veya devletlerarası işbirliği projelerinde aranan en önemli unsurlardır. Çünkü bölge devletlerinde hakim olan siyasi sistemlerin her biri ayrı bir örümcek ağıdır. Ağın kılavuz ipi ise sistemin merkezinde yer alan devlet liderinin elinde bulunmaktadır. Devletlerin her birinin rejim güvenliği kendi ağ sisteminin sağlamlığına bağlıdır, ki hiçbir lider tek bir ipin dahi kopması riskini alamaz durumdadır. Bu durum, her ülkeyi kendi siyasi bağımsızlık anlayışını değiştirmeden muhafaza etmeye yöneltmektedir. Böyle bir sistem yapısı bölge devletlerinin taviz sınırını daraltmakta, tek bir bölgesel egemenlikten ziyade, her ülkenin bağımsızlı̆̆ını ayrı ayrı koruyacak siyasi güç dengesi arayışına sürüklemektedir.

Bağımsızlı̆̆ bölge dışı aktörler ile olan işbirliğinde aramanın ilk nedeni bağımsızlığın kendisidir. Orta Asyalı siyaset uzmanı Farkhod Tolipov'un da belirttiği gibi, SSCB'nin dağılması, bölgedeki her devlete kendi istediği şekilde bağımsızlık uygulama imkanı sağlamıştır. Söz konusu uygulamalar, bölgedeki diğer bir devletin bağımsızlığına zarar verecek kadar sınır tanımazlığa yol açmıştır. Ülkeler arasında devam eden sınır sorunları, su paylaşımı ile ilgili yaşanan anlaşmazlıklar buna bir örnektir (Dadabaev, 2007). Bu tür bağımsızlık uyuşmazlıkları, ülkeleri çeşitli bölge dışı aktörler ile işbirliğine ya da zayıf devletler ile büyük güçler arasında meydana gelen bandwagoning ilişkisine yöneltmiştir. Çünkü bölgedeki zayıf devletler ile olan işbirliği ülkeleri bağımsızlıktan ödüne zorlarken, büyük güçler ile olan işbirliği onlara 'koruyucu entegrasyon' firsatı sunmaktadır (Allison, 2008, s. 185).

Bağımsızlığı koruyacak güç dengesi arayışının ikinci bir sebebi ise Orta Asya ülkelerinin siyasi yapılanma tarihidir. Buradaki tarihi sebebi, Rus yönetimi öncesi siyasi yapılanma ve bağımsızlık sonrası Rusya hegemonyası olarak ele almak mümkündür. Bölgedeki beş devletin SSCB öncesinden geçmişe uzanan tarihte belli bir devlet deneyimi yaşamış olmalarına rağmen ( $\mathrm{O}$ zamanlardaki devlet anlayışına göre: Hanlıklar, Kağanlıklar, Emirlikler) kabile veya etnik boylardan oluşmuş olmakla tam anlamıyla bir devlet tecrübeleri bulunmamaktadır. Dolayısıyla, bir diğer Orta Asya siyaseti uzmanının tanımladığı gibi, bölge devletlerinde 'tarihi meşruiyet deneyimi' zayıftır (Cummings, 2002, s. 33). Bu zayıflık doğal olarak ülkelere tecrübeli devletlerden yardım almayı ve onlarla işbirliğine girmeyi gerektirmiştir.

İkinci bir sebep olarak SSCB'nin dağılması ile başlayan ve günümüze kadar devam eden Rus hegemonyası, bölge devletlerini bir Rusya kadar etkili olan dengeleyici güç arayış1 içine sokmuştur. Ayrıca, bağımsızlığın ilk yılları her ne kadar Rus desteğini aratmış olsa da, Vladimir Putin'in iktidara gelmesi ile Rusya'nın yeniden büyük güç haline yükselerek diğer büyük güçler ile jeopolitik rekabete girmesi, dengeleyici güç arayışında bölge ülkelerine bir nevi firsat kapısı açmıştır. Çünkü Rusya'nın etki alanından

\footnotetext{
${ }^{2}$ Belirli faaliyetler üzerinde varılan seçmeli ortaklık. Ayrınıtlı bilgi için bkz: MITRANY, David, (1948). "The Functional Approach to World Organization”, International Affairs, 24 (3), s.358-359.
} 
tam olarak çıkma söz konusu olmazsa dahi, rekabet içerisindeki diğer güçlerle olan ilişkilere dayanarak Rusya'nın belli başı ı politikalarda geri adım atmasını sağlama imkanı doğmuştur.

Daha önce bağımsızlık tecrübesi yaşamamış yeni bir devletin başına geçmek Orta Asya liderleri için ayrı bir bağımsızlık arayış sebebi daha oluşturmuştur. Çünkü lideri oldukları ülkeyi baştan inşa etmekle devlet başkanları ömür boyu 'Halkın Atası', 'Arkadağ', 'Padişah' ve 'Peşvoi Millat' unvanlarını edinmişlerdir, ki bu unvanların daimiliği de ülkedeki rejim güvenliğini sağlayacak güç dengesine bağlıdır. Karizmatik lider olarak da nitelendirilen ve genelde liderlerin ömrü veya iktidarda kalma süresi ile sinırlı olan böyle bir rejim özelliği, bölgedeki her devletin diğer komşu devletlerden farklı bir uluslararası imaj, bir tanıtım oluşturmasını gerektirmiştir. Zira, her ülkeyi kendi tanıttığı imaj çerçevesinde algılayacak ve dolayısıyla mevcut rejimin yürüttüğü bağımsızlık politikasını destekleyecek bölge dışı aktörlerle olan işbirliği, liderlerin unvanlarını da meşrulaştırmaktadır.

Hem liderlik ünvanını, hem de rejim güvenliğini pekiştirecek birbirinden bağımsız imajlar ise şöyledir: Kazakistan'ın Avrupa ile Asya arasındaki köprü olduğu veya ekonomik olarak bir 'Asya leoparı' olduğu imaj1 (Nazarbayev, 2003); Özbekistan'ın tarihi zenginliklerin ve kültürel değerlerin merkezi olmakla doğu ve batıyı birleştiren ticari ve kültürel köprü olduğu imajı (Karimov, 2011); Türkmenistan'ın tarafsılılk stratejisi, Kırgızistan'ın ‘demokrasi adası' veya Dünya Göçmenler Oyunları nezdinde yeniden oluşturulmaya başlayan 'Göçmen uygarlığının merkezi' imajı vs.

Ayrıca, bağımsızlıkları koruyacak güç dengesinin bölge dışı aktörler ile olan projelerde aranması, bölge ülkelerinin kendi aralarında yaptıkları projelerin başarısızlığına neden olmaktadır. Bütün bir bölgesel aktör olarak hareket etmenin, dış güçler arasında tek tek gidip gelmekten daha sağlam ve avantajlı olduğunun farkında olsalar dahi, bölgedeki devletler, birtakım bölge içi sorunlar ve kısa vadeli çıkar politikalarına yenik düşmektedirler. İlişkilerin böyle gelişmesinde elbette ki dış aktörlerin de etkisi büyüktür. Bağımsızlığı büyük güçler ile işbirliğinde aratan sebepleri, genel anlamıyla bölgesel ve bölge dışı faktörler çerçevesinde değerlendirmek mümkündür.

\subsection{Bölge İçi ve Bölge Dışı Faktörler}

Bağımsızlık sonrası Orta Asya ülkeleri, ülke egemenliğini pekiştirme işlemleri ile ülkelerarası entegrasyon ilişkilerini aynı zamanda yürütmek zorunda kalmışlardır. Bu durumda, kendi aralarında entegrasyon oluşturmanın yanı sıra, birden fazla büyük güç ile işbirliği içine girmek, bölge devletleri tarafından egemenliği pekiştirmenin bir yolu olarak tercih edilmiştir. Böylesine paralel bir gidişatta, yeni elde edilen bağımsızlık gücünün zayıflığı ve her ülkenin kendi devlet inşasına verdiği ağırlık, bölge içi entegrasyonu aksatırken, bölgenin dünyaya açılışı ile gelen dış güçlerin akını, bağımsızlığı dış güçler arası manevralarla pekiştirme eğilimini arttırmıştır.

Bağımsızlık güvencesinin devletlerarası projelerde aranmasının bölge kaynaklı nedenlerinin başında, ülkelerdeki bağımsızlık yanlısı hareketlerin zayıf olması gelmektedir. Gerçekte, hem yönetici sınıf, hem de halk kesimlerinin çoğu tabi oldukları sosyalist sistemden ayrılma gibi bir istek taşımamaktaydılar. Örneğin, 1990 ve 1991 yılları arasında kabul edilen bağımsızlık bildirgeleri ve SSCB'nin geleceğine dair yapılan referandum sonuçlarına bakıldığı zaman, Baltik ülkeleri, Gürcistan, Ermenistan ve Moldova halkı ülkelerinin bağımsızlı̆̆ından yanayken, Orta Asya genelinde her 10 kişiden 9'u birliğin korunması yönünde oy kullanmıştır (Olcott, 1998, s. 3).

Aynı coğrafyayı, ortak kültür ve tarihi paylaşmanın yanı sıra SSCB döneminde ortak sosyal ve ekonomik alt yapı sistemine bağlanmış olan bölgedeki beş devletin, bağımsızlık sonrası karşı karşıya kaldıkları yönetim sorunları da aynıydı. Tıpkı alt yapı sistemindeki bağımlılık gibi ülkelerarası işbirliğini çıkmaza sokan faktörler de bir zincir şeklinde devam etmektedir. Hareket noktasına göre değişse de söz konusu ilişki zincirinin bölgedeki etnik yapılanmadan başladığını söylemek mümkündür.

SSCB çatısı altında çeşitli etnik grupları bir arada tutan merkezi yönetimin sona ermesi ve ülkelerarası sınır çizme politikası sonucu, uzun zamandır sıkı ilişkiler içinde yaşayan bölge halkı birbirinden ayrılmış, halkın önemli bir kısmı da sınırları içinde kaldığı devletlerde etnik azınlık konumuna gelmiştir. Örneğin, Kırgızistan, Türkmenistan ve Tacikistan'daki Özbek azınlıklar, Özbekistan'daki Tacik azınlık, Kazakistan ve Kırgızistan'daki Slav kökenli azınlıklar vs. Bunlardan Slav kökenli kesim bölgedeki Rus hegemonyasının bir enstrümanı iken, sınır bölgelerinde yaşayan Orta Asya kökenli azınlıklar ülkelerarası sınır meselelerini 
zorlaştırmakta ve hepsi birlikte aynı zamanda azınlık hakkı ve statü ile ilgili birtakım meselelerle batı ülkelerinin dikkatini çekme rolüne sahiptirler.

Özellikle sınır bölgelerindeki etnik anklavlar ${ }^{3}$ bölge devletleri arasındaki sınır anlaşmazlıklarının temelini oluşturmakta, sınır çizgilerinin belirlenmemiş olması da yasadışı silah satışı, uyuşturucu ticareti ve radikal dini grupların karşılıklı akını gibi güvenlik problemlerine yol açmaktadır. Aslında tüm bunlar bölge devletleri arasında bir entegrasyon, bir ortak hareket sebebi iken, gerçekte bunun tersi olmakta, her ülke kendi doğru bulduğu şekilde ve kendi imkanlarına göre tedbirler uygulamaktadır. Örneğin, Rusya ve Çin ile paylaşılan sınırlar bu iki devletle işbirliği nezdinde belirlenmişken, bölgedeki beş devletin birbirleriyle paylaştıkları sınırlar bazen geçişe kapatılmakta, bazen de karşı tarafın askeri baskısı altında kalmaktadır. Burada bölge devletleri ile masaya oturmanın gerektirdiği siyasi ödünlerin yerine, bölge dışı güçler ile yapılan işbirliğinin, daha doğrusu bandwagoning'in daha kârlı bulunduğu görülmektedir. Zira bu tür işbirliğinde, yukarıda sözü edilen sınır, güvenlik veya ulaşım meselelerinin çözümü ile ilgili masrafların, Çin'in "Tek Yol, Tek Kuşak" planı, Rusya önderliğindeki “Avrasya Ekonomik Birliği”" veya ABD tarafindan desteklenen "Büyük Orta Asya" stratejisi gibi ortak projelerin hayata geçirilişi sırasında mevzubahis büyük devletlerce giderilmesi beklenmektedir.

Siyasi tavize dayalı bölge içi işbirliğindeki aksamaların diğer bir sebebi ise liderler arasındaki değişen ilişkilerdir. Bölgedeki her liderin 'bir devlet' konumunda olması da liderler arasındaki ilişkinin aynı zamanda devletlerarası ilişkiyi teşkil ettiği anlamına gelmektedir. Bu konuda Türkmenistan lideri tarafsızlık politikasının arkasında dururken, Kırgızistan'da devrim yoluyla gerçekleşen lider değişimleri ve Tacikistan'daki kalkınma firsatlarının azlığı, bölgesel işbirliği tartışmalarında Kazakistan ile Özbekistan'ı öne çıkarmaktadır. Zayıf devletler ile işbirliği adına ülkesinin bağımsız gelişiminden tavize varamayacağını söyleyen Kerimov'a (Rasov, 2012) karşı, Kazakistan lideri Nazarbayev: "Kazakistan bölgesel entegrasyonun güçlü bir taraftarıdır", "Biz bölgedeki diğer ülkeler böyle bir işbirliğinin önemini anlayacak derecede olgunlaşana kadar bekleriz" (Nazarbayev, 1997, s. 66) imajıyla entegrasyon yanlısı politikasını sürdürmüştür.

Tüm bunlara bakıldığında, her ne kadar rejim güvenliği konusunda birbirlerini destekler gibi görünseler de, sahip oldukları kalkınma kapasiteleri ve avantajları arasındaki farklılıklar ve bölgesel sorunların çözümü ile ilgili görüş ayrılığı, ülkelerin bağımsızlıkları 'Orta Asya Entegrasyonu' çerçevesinde değil de, bölge dışı güçler ile işbirliği nezdinde muhafaza etmelerine neden olduğu görülmektedir. Ayrıca, bağımsızlığın daha ilk on yılında Tacikistan'ın iç savaşa sahne olması, Özbekistan'ın İslami hareketlerle mücadeleye girmesi ve Rusya'nın da henüz toparlanmamış bir hal sergilemesi bölge devletlerini alternatif güvenlik arayışına sürüklemiştir. Daha bağımsızlığın ilk yıllarından itibaren liberal reformlara yönelik destek arayışına düşen Kırgızistan ve Kazakistan'ın dışarıya açılması ise ekonomik yönde başlamıştır. Her ülkenin kendi ihtiyacına ve kalkınma firsatlarına göre işbirliği seçimi bölge ülkeleri arasındaki mesafeyi büyütürken, bu ülkelerin egemenlik inşasında rol almak isteyen dış aktörler sayısının giderek artması da Orta Asya hükümetleri açısından güç dengesi arayış alanını genişletmiştir.

Bölge ülkelerinin bağımsızlık inşasında rol alan dış aktör sayısındaki artış aynı zamanda söz konusu aktörlerin kendi aralarında jeostratejik rekabete yol açmıştır. Stratejik denge arayışının bir sonucu olan bu rekabet, aynı zamanda Orta Asya ülkelerinin kendi aralarında meydana gelebilecek entegrasyon girişimlerinin yolunu kesen dış etkenlerin başında yer almaktadır. Çünkü, Orta Asya ülkeleri açısından, güçler arası rekabeti kendi ulusal çıkarları çerçevesinde kullanmak, bölge içi işbirliğinden daha kârlı bulunmaktadır. Genel anlamıyla Rusya, Çin, ABD ve diğer aktörler olarak gruplandırılabilecek dış aktörleri, kendi içerisinde Rusya-Çin işbirliğine yakın olanlar ve Batı taraftarları olarak da ayırmak mümkündür. Zira, bölge ile sınırdaş olmaları, otoriter yönetimi desteklemeleri ve Şanghay İşbirliği Örgütü başta olmak üzere bölgesel projelerde birlikte yer almaları sebebiyle Çin ile Rusya işbirliği, bölgeden uzak bulunan ve otoriter yönetime karşı tutum sergileyen ABD'ye karşı bir gruplaşma olarak değerlendirilmektedir. Bundan dolayıdır ki, Orta Asya ülkelerinin bağımsızlık için denge arayışında, yüz seksen dereceli dönüşüm Rusya ile ABD arasında gerçekleşmekte, ülke içerisindeki yönetici sınıf ayrımında da Çin veya başka herhangi bir dış aktörden yana değil, Rusya ve ABD’den yana bir bölünme söz konusudur.

\footnotetext{
${ }^{3}$ Yabancı bir ülke toprakları ile çevrelenmiş başka bir ülkeye ait bölge. Ayrıntılı bilgi için bkz: VINOKUROV, Evgeniy, (2007). Теория Анклавов, [А Theory of Enclaves], Kaliningrad: Terra Baltika.
} 
Orta Asya, Rusya Federasyonu'nun tarihi arka bahçesi ve günümüz 'yakın çevre' politikasında da vazgeçilmez bir 'etki alanı' olmasından dolayı, bölge ülkelerinin bağımsızlıktan bugüne geliştirdikleri güç dengesi stratejileri, Rus üstünlüğünü dengeleme yönündedir. Bu bakımdan Rusya'nın 2016 dış politika açıklamasında Orta Asya bölgesinin ilk sıralarda yer alması (Dünya Bülteni, 29.04.2016) Rusya'nın bölgeye yönelik yaklaşımının bir göstergesi iken, Batı ülkeleri ile devam eden karşı direniş, Orta Asya ülkelerindeki denge arayışını canlı tutacaktır.

Siyasi emellerini öne sermemekle birlikte ekonomik açıdan Rusya'yı geride birakma potansiyeline sahip olan Çin Halk Cumhuriyeti, Orta Asya'daki güç dengesinin ucunu tutan ilk üç aktörden biridir. Bölge ülkelerinin bağımsızlık inşasında rol almadaki ilk hedefi, kendi siyasi sistemini ve toprak bütünlügünü güvene almak olmuştur. Ürettiği mallara pazar sağlama ve enerji ihtiyaçlarını karşılama girişimleriyle bir sonraki hedeflerini tamamlayan Çin, Orta Asya devletlerinin birbirinden farklı bağımsızlık arayıșına girmesinde etkili rol oynamıştır. Çünkü ilk yıllarda bölgenin geneline hitap eden bir dış politika izlemiş olmasına rağmen, zamanla bölgeye yönelik hedeflerini ilgili ülkenin mevcut özelliklerine göre belirlemeye başlamıştır.

Örneğin, Kırgızistan ile Rusya arasındaki enerji işbirliği anlaşmasının iptalinin ardından Kırgızistan'daki Hidroelektrik Santral Projelerine ortaklık girişimleriyle ülkenin hidroelektrik enerji potansiyeline odaklanırken (Clark, 2016), Özbekistan ile olan ilişkilerinde ülkenin radikal dini akımlarla mücadeleye dayalı geçmişinden ve Afganistan ile sınırdaş olmasından kaynaklanan güvenlik meselelerini ön plana çıkarmaktadır (Koparkar, 2017). Kazakistan'a yönelik yatırımlarının yüzde 50'sini petrol üretimine ayırmakla ülkeden senelik 10.88 milyon ton petrol ithal eden Çin, 2019 verilerine göre Türkmenistan'dan senelik 47.9 milyar metreküp doğalgaz temin etmektedir (Hellenic Shipping News, 2019 ve The Third Pole, 2019) . Bölge ülkeleri arasında dış yatırımlara en çok bağımlı olan Tacikistan'da ise toplam yatırım miktarının yüzde 60'dan fazlasını gerçekleştirmekle ve senede yaklaşık 2 milyar dolar yatırım yapmakla Çin ülkedeki en büyük yatırımcı konumuna gelmiştir (Avesta Information Agency, 2019).

Orta Asya'daki Rusya ve Çin işbirliğine karşı meydan okuyan üçüncü bir güç olarak ABD, bölgedeki güç dengesi arayışına yeni bir yön katmış, Batı istikametine yol açmıştır. Gerçekte, Brzezinski'nin de belirttiği gibi Amerika, bu bölgeye egemen olmak için çok uzaktır, lakin ilgi dışı bırakamayacak kadar da güçlüdür (Brzezinski, 1998, s. 148). Bu bakımdan, Orta Asya'y1 ABD’nin Avrasya ve Güney Asya'ya yönelik dış politikasının bir alt basamağı olarak görmek mümkündür. Lakin, 2001 yılında güvenlik amaçlı başlatılan girişimlerin, daha sonra Özbekistan dış politikasındaki sallanmalar ve Kırgızistan'daki siyasi rejimin devrilmesiyle devam eden etkisi, ABD'nin Orta Asya bölgesine teoride görüldüğünden daha yakın geldiğini göstermiştir. Bölge ülkelerinin doğrudan taraf olduğu bir örgütsel projede yer almasa dahi, küresel güç tavrıyla tek taraflı olarak geliştirdiği Büyük Orta Asya Projesi ve bu projenin uzantısı olan günümüz C5+1 girişimleriyle ABD, Orta Asya bağımsızlığını, özellikle Rus hegemonyasına karşı dengeleyecek en etkin güç konumundadır.

Ayrıca, bağımsızlıktan bugüne bölgede aktif olan Rusya, Çin ve Batı (ABD ve AB) ülkelerinin taraf oldukları projelerin sayısı, günümüzde Hindistan, Türkiye, Japonya ve İran başta olmak üzere diğer Orta Doğu devletlerinin de taraf olduğu projeler ile tamamlanmaktadır. Bu projeler ve taraflarının, yeri geldiğinde bölgeye hakim olmak isteyen söz konusu üç büyük güce 'stratejik yardımcı' rolü üstlendikleri öne sürülse de, ticari ve kültürel işbirliği nezdindeki bu tür projelerin Orta Asya ülkelerinin siyasi faaliyet alanını genişlettiği bir gerçektir.

Bağımsızlığın ilk yıllarında Orta Asya'yı Rus hegemonyasından kurtaracak aktörler ile birlikte bölgeye giriş yapan Türkiye Cumhuriyeti, yeni oluşan Türk devletlerine laik demokratik yönetim modeli olarak sunulmuştur. Edilgen olmanın getirdiği başarısızlık sonucu Türkiye, Orta Asya ülkeleriyle baş-başa ve bağımsız işbirliğine yönelmiş, ki bölgede Rusya ve Çin'in varlığı bu işbirliğini zorlaştırmıştır. Zamanla, dini, kültürel ve ekonomik alandaki engellerin hemen hepsi aşılmış, özellikle yapı-inşaat alanında en önemli ortak konumuna gelmişse de, Türkiye'nin bölgede siyasi güç dengesi olarak var oluşu, Rusya-Türkiye ilişkilerinin gidişatına göre değişebilmektedir.

Tacikistan'1 Fars dili konuşulan ülkelerden oluşacak 'Pax Iranica' (Laumulin, 2011) birliğine dahil etme planlarının başarısız olmasına rağmen, bölge sınırlarına yakın olması, Kazakistan ve Türkmenistan ile Hazar denizi kıyılarını paylaşıyor olması ve nihayet Rusya ile ilişkilerinin sabit ilerlemesinin sağladığı 
avantajlarla İran'ın Orta Asya'ya girişi diğer aktörlere nazaran daha kolay olmuştur. Siyasi açıdan Rus hegemonyasına karşı çıkmamakla birlikte İran, bölge ülkelerinin siyasi bağımsızlığını güçlendirecek ekonomik yatırımlar ve enerji alanında alternatif sunan aktörlerdendir.

Şanghay İşbirliği Örgütü'ne yeni dahil olan ve bu yolda Çin'in yayılma hareketlerini izleme firsatı bulan Hindistan'ın Orta Asya'daki varlık sebebinin başında Tacikistan ve Afganistan aracılığıyla Pakistan'ı çevrelemek gelmektedir. Bundan dolayı Tacikistan ile askeri ve güvenlik alanındaki ilişkileri muhafaza etmeye çalışmakta, Pakistan-ABD-Hindistan ilişkilerinin niteliğine göre de yeri geldiğinde Rusya ile birlikte hareket etmektedir. 2012 yılında geliştirdiği “Orta Asya'yı Birleştirme” projesi (Troyitskiy, 2013) nezdinde enerji, tıp ve eğitim alanlarında işbirliğine imza atmakla Hindistan, bölgedeki Rus ve Çin üstünlügünü dengeleme sırasını beklemektedir.

2001'de ABD'nin Orta Asya'ya girmesinin ardından 2004 yılında "Orta Asya+Japonya" diyaloguna (Nurgaliyev ve Shaymergenov, 2007) imza atan ve bölge ile ne coğrafi, ne de kültürel yakınlığı olmasına rağmen sürekli yardımda bulunup da devletlerin iç işlerine karışmayan iyi niyetli aktörlerden biri de Japonya'dır. Japonya'nın Orta Asya'daki amacı, tarihsel rakibi olan Çin'i dengelemek olarak görülse de, "Büyük Satranç Tahtası"nda Çin ile Japon yakınlaşması ABD'nin engel olması gereken bir durum olarak ortaya çıkmaktadır. Ayrıca, Japon bilim adamı Kawato'nun Orta Asya ile ilgili konuşmasında Özbekistan ile ilişkilere ayrı bir vurgu yapması ve Afganistan'daki istikrar ile sosyalist toplumların zamanla reform edilmesi yönündeki dış politika maddelerini dile getirmesi (Leung, 2007), Japonya'nın Orta Asya'da hangi gücü dengeleme için var olduğunu ortaya koymaktadır.

Tüm bunlara bakıldığında, Orta Asya ülkelerinin 1991 yılında başlattıkları bağımsızlık inşasının henüz tamamlanmamış olduğu ve bu bağımsızlığa giden yolda tek bir hegemonya karşı güçler arası denge sağlamanın bölge devletleri açısından kolay olmadığı da görülmektedir. Zira söz konusu güç dengesi sadece bölge devletleri ile alakalı olmayıp, mevcut güçlerin bölge dışı hedefleriyle de doğrudan bağlantılı durumdadır. Lakin, bağımsızlığı korumak için gereken potansiyele henüz sahip olamamışken, bölge içi entegrasyonun var olan potansiyeli de gerileteceği varsayımıyla, bölge devletlerinin bağımsızlık stratejileri, zaman ve duruma göre farklı biçim alarak dış güçler ile olan işbirliğinde aranmaya devam etmektedir. Nihayetinde, ister simgesel olsun, ister fonksiyonel, mühim olan yukarıda bahsedilen dış güçlerle varılan projeler devam etsin, ki çok yönlü çıkarlar işbirliği adı altına bürünsün maksadı ağırlık kazanmaktadır.

\subsection{Orta Asya'da Entegrasyon ve İşbirliği Projeleri}

\subsubsection{Bağımsız Devletler Topluluğu}

Her ne kadar Rusya'nın Birlik Devletleri üzerindeki nüfuzunu devam ettirme politikası olarak görülse de Bağımsız Devletler Topluluğu (BDT), diğer taraf devletler gibi Orta Asya ülkelerinin de kendi çapında çıkarlarını karşılamıştır. Söz konusu çıkarlar, daha önce devlet tecrübesi olmayan ülkelerin siyasi bağımsızlık yolunda karşı1ıklı bilgi alışverişinin ortak bir çatı altında yürütülmesinden ibaretti.

Minsk görüşmelerine iştirakının belirsiz sebeplerden ötürü iptal edildiği Kazakistan lideri Nazarbayev'in da belirttiği gibi, BDT'nin Slav ülkeleri tarafından kurulması, Müslüman-Hıristyan, SlavTürk hatta Avrupa-Asya gerilimini başlatarak eski Soviyet coğrafyasını yeni bir krize sürükleyecekti. Ayrıca, Sovyetler Birliği’nin sona ermesi, bütün bir organizmanın parçalanması demekti. Böyle bir krizi tek başına aşmanın güçlügünü herkes kabul etmektedir (Brzezinski ve Sullivan, 1997, s. 351). Gerçekten de SSCB'nin dağılması, eski birlik ülkelerine bağımsızlık statüsünü kazandırdığı kadar söz konusu bağımsızlığı sürdürme sorumluluğunu da beraberinde getirmiştir. Bu bakımdan Orta Asya devletlerinin BDT'ye dahil olması, etnik ve dini farklılıklarla temasa yol açarak Rusya'nın ülke bütünlügüne katkı sağladığı gibi, bölge ülkelerinin radikal eylemciler ile baş başa kalmasını önlemiştir.

Topluluğun Orta Asya odaklı değerlendirildiği zaman, bölge ülkeleri, diğer ülkeler ile diplomatik ilişkileri kurmadan başlayıp kendi egemenlik yetkilerini idrak etmeye dek uzanan süreçte kendi aralarında ve Rusya ile karşılıklı işbirliğine ihtiyaç duymaktaydılar. Kapalı bir bölge olarak sahip oldukları doğal kaynakların dış pazarlara çıkışı, dış yatırımların çekilmesi, üretim alanındaki bağımlılık, mevcut sınır sorunları ve henüz bağımsız bir askeri güce sahip olmadan ülke güvenliğinin sağlanması gibi devlet inşasını kökünden etkileyen pek çok faktör BDT veyahut başka bir isim altında ortak hareketi gerektirmekteydi. Bu hareket bölgede öne çıkan mevzulardan sadece birinin, örneğin Kolektif Güvenlik Anlaşması Örgütü ismi 
altında da yürütülebilirdi, ki her iki türlü de Moskova önderli siyasi bağımsızlığa tutunma manası taşıyacaktı. Sadece BDT gibi sembolik değil, daha fonksiyonel bir seslenişi olacaktı, kurucu anlaşma ise:

"Üye devletlerden biri veya birkaçının bağımsızlığına, güvenliğine ve ülkesel bütünlüğüne veya uluslararası barış ve güvenliğe yönelik tehditlerin oluşması durumunda, üye devletler anında karşılıklı danışma mekanizmalarını harekete geçirecek, gerektiğinde askeri güç kullanarak mevcut tehdidi giderme tedbirlerini alacaktır" (Bağımsız Devletler Topluluğu Tüzüğü, Madde 12) şeklinde geleneksel bir içeriğe sahip olacaktı.

Nihayetinde, günümüz Bağımsız Devletler Topluluğu olarak, bağımsızlığın ilk senelerindeki gerçekten de ihtiyaç duyulan görevini belli bir ölçüde tamamlayacak, zamanla fonksiyonelliğini yitirecekti. Buna delil olarak örgütün kurulma gerekçesini oluşturan kurucu anlaşmadaki bağımsızlık, güvenlik ve ülke bütünlüğü ile ilgili ilkelerin artık geçersiz hale geldiğini söylemek mümkündür. Özellikle Ukrayna devlet bütünlügünün ihmal edilmesi, bu durumun Orta Asya'yı, özellikle Kazakistan'ı tedirgin etmesi söz konusu anlaşmanın geçersiz hale geldiğini göstermektedir.

Günümüz itibarıyle BDT’yi Orta Asya ülkeleri açısından, bağımsızlıkların inşa süreci için girilen bir işbirliği olarak nitelendirmek mümkündür. Daha sonra arka arkaya gelen Rusya merkezli projeler (EurAsEC, CU) karşısında bağımsızlığ 1 koruma ve tek merkezli projeleri dengeleme süreci başlamakta, dengeleme yelkeni ABD, Çin ve diğer yönlere açılmaktadır. Ayrıca, bu noktadan sonra bölge devletlerinin bekası sadece bağımsızlık değil, bağımsızlık-rejim güvenliği şeklinde sürdürülmektedir. Bu durum batının mevcut rejimleri değiştirme çabasına bir direniş olarak Rusya'nın etkin dengeleyici rolünü de muhafaza etmektedir.

\subsubsection{Orta Asya Sınırları İçinde Entegrasyon Girişimleri}

Her ne kadar, Minsk toplantısına dahil edilmemekle üç büyük Slav devleti tarafindan dışlanmış olma durumuna karşı bir tepki olarak ortaya çıktığı öne sürülse de, bağımsızlık sonrası Orta Asya ülkelerinin ilk adımı birlikte atmalarını gerektiren birtakım somut meseleler mevcuttu. Geniş bir yapıya sahip olmakla BDT, bölge ülkelerine has meselelere yeterince hitap edemezken, Rusya veya Ukrayna gibi mukayeseli üstünlüğe sahip devletlerle beraber koşmayıp, zayıf ekonomilerini, güvenlik sorunlarını ve idari aksamalarını düzeltme yönünde bölgesel işbirliğine imza atmak Orta Asya devletleri açısından oldukça rasyonel bir adımdı. Lakin ayakta kalma çabasıyla her türlü yolların denendiği ve her yolun da merkezi Moskova'ya bağlandığı bir döneme denk gelmesi söz konusu işbirliği hırsına mâni olmuş, firsatların olduğu dönem geldiğinde artık ülkeler arasındaki mesafe büyümüş birleşme hırsı ortadan kalkmıştır.

1993 ile 1995 yılları arasında oldukça hızlı ilerleyen ve ekonomik, askeri ve siyasi entegrasyonu amaçlayan Orta Asya Birliği çerçevesindeki girişimlerin gerçekleşme potansiyelini, günümüz entegrasyon girişimlerine en çok karşı çıkan Özbekistan'ın o yıllardaki dış politikasına bakarak anlamak mümkündür. Zira Kerimov'un 1997 yılında dile getirdiği: "Orta Asya halkları arasında entegrasyon her daim mevcuttu ve doğal olarak muhafaza edilecektir. Söz konusu birleşmenin geleceği bir hayal veya bir projeden ibaret değildir, bu sadece yasal ve politik bir kurumsallaşmay1 gerektiren bir gerçektir" (Tolipov, 2010, s. 110) kanaati, bölgesel entegrasyona karşı devamlı direniş gösteren Özbekistan'ın dahi ilk yıllarda birlik yanlısı olduğunu göstermektedir.

Beklenen fonksiyonelliği gösterememesine ve zaman zaman gündemden kaldırılmış olmasına rağmen bölgesel entegrasyon çalışmaları, Orta Asya Birliği, Orta Asya Ekonomik Topluluğu ve Orta Asya İşbirliği Örgütü isimleri altında 2000'li yıllara kadar devam ettirilmiştir. Daha sonra 2001, 11 Eylül olayları bölgeye ABD'yi getirmiş olmakla beraber, Rusya'nın Orta Asya'yı yeniden kazanmasına da yol açmıştır. Tacikistan ve Özbekistan başta olmak üzere bölge güvenliğine yönelik artan tehditler, bölge ülkelerine Rusya ile hem siyasi, hem de askeri işbirliğini güçlendirmeyi zorunlu kılmıştır. Tüm bunların Rusya'da Vladimir Putin yönetiminin başladığı, dolayısıyla eski Sovyet toprakları üzerindeki hakimiyet politikasının yeniden yapılandırıldığı döneme denk gelmesi de Orta Asya Birliği’nin geleceğini belirlemiştir.

2004 yılında Rusya'nın tam üye olarak katılması Orta Asya İşbirliği'ni sembolik hale getirirken, 2005 'te örgütün Avrasaya Ekonomik Topluluğu ile birleştirilmesi bölgesel entegrasyon fırsatını tamamen ortadan kaldırmıştır. Bu suretle "Orta Asya İşbirliği Örgütü kendi yolunu tamamlamıştır" (Regnum Haber Ajansı 10.2005) açıklamasını yapan Nazarbayev, 2007 yılında Orta Asya Birliği’ne yönelik girişimlerin yeniden başlatılması ile ilgili çağnıda bulunmuş, bu sefer karşısında yıllar önceki desteği değil, her biri kendi 
ulusal çıkarına dayalı bağımsızlık arayışına düşen ülkeleri bulmuştur. Zira her devletin kalkınma firsatlarına ayrı ayrı hitap eden dış yardımlar, ekonomik, dolayısıyla siyasi yatırımlar, bölgedeki zayıf devletlerle olan işbirliğinden daha kârlı bulunmuştur. Dış dünyaya yönelik böylesine heterojen bir açılış gittikçe bölge ülkelerinin kalkınma kapasiteleri ve avantajları arasındaki farkı büyütmüş, devlet bekası ihtiyaca göre değişen dış güçler aracılığıyla sürdürülür olmuştur.

\subsection{3. “Avrasya Birliği”ne Yönelik Projeler}

Gerçekte, hem fiziki, hem de siyasi sınırlarının tartışmaya açık olduğu bir bölgesel isimlendirme olarak Avrasya topraklarında meydana gelen Avrasyacılık akımı ile Avrasya işbirliği adı altında yürütülen projeler arasında önemli ölçüde içerik uyuşmazlığı söz konusudur. Felsefi bir kuram olarak Avrasyacılık başlı başına geniş bir araştırma alanı oluşturmaktadır. Kavram çatışmasını önlemek ve mevcut çalışma konusunun dışına çıkmamak amaciyla bu başlıkta, Avrasya işbirliği adı altında varılan projelere ve bu projelerin Orta Asya'daki siyasi sonuçlarına ağırlık verilecektir.

Genel anlamıyla Gümrük Birliği, Ortak Ekonomik Saha ve Avrasya Ekonomik Birliği evrelerinden oluşan günümüz Avrasya işbirliği projeleri, SSCB'nin dağılmasını müteakip arka arkaya oluşan siyasi projelerdeki aksamaların, somut ve uygulanabilir bir işbirliği ile giderilmesini öngörmektedir. Nursultan Nazarbayev'in öne sürdüğ̈̈ ve Avrasya entegrasyonunun, BDT, Kolektif Güvenlik Anlaşması Örgütü, Avrasya Ekonomik Topluluğu ve Şanghay İşbirliği Örgütü'nü kapsayacak bir proje olduğu iddialarına (Dutkiewicz ve Sakwa, 2015) rağmen, günümüz Avrasya Ekonomik Birliği (AEB), yukarıda sayılan projelerin kapsamı altındaki bir iktisadi branşı oluşturmaktadır. Söz konusu iddiaların kaynaklandığı ve proje evrelerinin Avrasya Entegrasyonu'na kadar devam edeceği varsayımları ise Rusya dışında savunucularını kaybetmekte, taraf devletleri siyasi bağımsızlık uğruna ekonomik işbirliğinden dahi çekilme durumuna hazır eylemektedir.

Orta Asya açısından Avrasya nezdinde işbirliği, mevcut ekonomik zayıflı̆̆ 1 giderme ve ekonomik kalkınma aracılığyla devlet egemenliğini pekiştirme amacından ibarettir. Lakin bölge devletleri tarafından istenilen Avrasyacıl işbirliği ile gerçekleşen projeler arasında birtakım farklar görülmektedir. Bağımsızlığın ilk yıllarında, SSCB'nin geri inşa edilemezliğinin kabulü, özellikle Orta Asya'da ideolojik/politik bir kimlik inşasını gerektirmişti. Bölgede önder bir lider olarak Nazarbayev, Avrasya adı altındaki bölgesel bir kimlik oluşturma teklifinde bulunmuştur. Çünkü Avrasyacılık ilgili dönem açısından oturmuş bir ideoloji teşkil eden ve ilk senelerde ihtiyaç duyulan Rusya'nın önderlik rolünü de makul k1lan bir kimlikti. Lakin söz konusu teklif ilk dile getirildiğinde Rus basını dahil olmak üzere istenilen desteği bulamamıştır. 2000 sonrası Putin yönetimi tarafından destek geldiği zaman projenin bölgesel kimlik inşasındaki rolü ortadan kalkmış, geriye sadece iktisadi firsatlar kalmıştır.

Bölge devletlerinin Avrasya işbirliğine yönelik beklentilerinden bir diğeri de Asya ile Avrupa arasında bölgesel bir köprü rolünü üstlenerek $\mathrm{AB}$ ve Çin başta olmak üzere diğer bölgesel aktörler ile çok taraflı ilişkilere imza atmak (Dutkiewicz ve Sakwa, ss. 54-56), böylece Rusya hegemonyasını dengelemekti. Fakat Avrasya Ekonomik Birliği evresine gelmiş olan günümüz Avrasyacılığına bakıldığında, Orta Asya Rusya'nın söz konusu bölgesel aktörleri dengelemek amacıyla oluşturduğu kutup içerisinde gözükmektedir. Bu durumda bölge ülkeleri bağımsızlıklarının zedeleneceği kaygısıyla ilk yıllarda öne sürdükleri ve ulus üstü bir kurumun oluşturulması ile ilgili girişimlerden desteklerini çekmekte, birliğin iktisadi ilişkilerle sınırlı kalmasını istemektedirler. Lakin, bölge ülkelerinin taraflar arası eşitlik ve pragmatik ekonomiye dayalı işbirliğinden yana istekleri, gerçekte Rusya merkezli jeopolitik entegrasyon hareketleri ile karşı karşıya kalmaktadır.

Ayrıca, günümüz Avrasya Ekonomik Birliği Orta Asya açısından, Rusya'nın dengelenmesini gerektiren bir oluşum olduğu kadar, Çin'in Orta Asya'daki ilerleme gücünü dengeleyici role de sahiptir. Çünkü devamlı Rus gücünü dengeleyici bir aktör olarak ele alınan Çin, günümüzde artık dengelenmesi gereken bir güç konumuna gelmiştir. Bölgedeki siyasi istikrar ve güvenlik alanlarında Rusya ile ortak kanaatte olmasına rağmen, Çin'in bölgedeki iktisadi gücü, yine iktisadi bir oluşum ile dengelemeyi gerektirecek kadar büyüktür. Zira 2000 yılında 1 milyar dolar ile başlayan ve günümüzde yaklaşık 50 milyar dolara çıkan ticari ve yatırım ilişkileriyle (Clark, 2016; Serikpayev, 2019) enerji sektörü başta olmak üzere ekonomik alanda devlet bütçesini etkileme kapasitesine sahip olmak, aynı zamanda ilgili ülkedeki siyasi denge arayışı açısından etkin bir rol kazandırmaktadır. 
SSCB zamanında oluşturulan ve devlet sistemleri arasındaki iktisadi bağlılıktan kaynaklanan karmaşıklığa çözüm bulmak amacıyla başlatılan projelerden biri olarak Avrasya Ekonomik Birliği, ticaret, iş, hizmet ve üretim alanlarında ortaklığa yönelmekle söz konusu bağlılığın muhafazasını öngörmektedir. Siyasi ilişkilerden bağımsız olarak yürütülmesi pek mümkün olmayan bu tür iktisadi ortaklığın reddedilmesi de kredi-borç, yatırım-ambargo ikilemleriyle yine dış siyasete yansımaktadır. Rusya önderliğinde geliştirlen projelerden güncelliği ve fonksiyonelliği ile fark yaratan günümüz Avrasya Ekonomik Birliği, Orta Asya'daki rejim güvenliğinin birden bir garantörü olan ekonomik güvenlik açısından hem dengeleyici, hem de dengelenmesi gereken bir aktör olarak gündemdedir.

\subsection{4.Şanghay İşbirliği Örgütü}

"Orta Asya, göklerin Çinlilere verdiği pastanın en lezzetli dilimidir" ("On the Eve of the SCO”, 2016) iddialı generale sahip Çin ile "Orta Asya ülkelerinin, Alma-Ata merkezli bir federal bölge oluşturularak Rusya'ya bağlanmasını" (“Jirinovskiy Ins”, 2014) gerekli gören iddialı politikacıya sahip Rusya'yı istedikleri bölgede buluşturmakla Şanghay İşbirliği Örgütü (ŞïÖ), bölge ülkelerinin bağımsızlık arayışında birtakım fırsatlar sunmaktadır. Mevcut ülkelerde iç egemenliğin pekiştirlmesi ve dış bağımsızlığın korunması ile birlikte söz konusu bağımsızlığa bedel olan rejim güvenliğine verilen destekler, Şı̈̈ karşısında Orta Asya'daki her devletin kapısını açmaktadır.

ŞiÖ’nün Orta Asya devletlerinin güç dengesi arayışındaki önemini belirleyen ilk unsur Rusya ile Çin'i birbirini dengeler konuma getirmesidir. Bu durum aynı zamanda Şı̈Ö'yü baskıcı ve katı bir entegrasyon amacından uzak tutmaktadır. İkisinin de yakın çevre alanına dahil olması sebebiyle, Rusya ile Çin'in Orta Asya'da birbirini dengelemesi kaçınılmazdı. Lakin söz konusu dengelemenin sert bir rekabetten ziyade işbirliği nezdinde meydana gelmesi, Rusya'nın bölgedeki varlığını daimi kıldığı ve Çin'in bölgeye girişini kolaylaştırdığ kadar Orta Asya ülkelerini de iki dere arasında kalma endişesinden kurtarmıştır. Her ne kadar $A B D$ ve Batı yayılımını engelleme konusunda birlikte hareket ettikleri görülse de, aralarında ciddi farklıkların bulunduğu iki büyük güç ile aynı anda işbirliği yapmak, bölge devletlerinin dengeleme aracı olan 'çok yönlü' dış politika stratejilerinin uygulandığı izlenimini de yaratmaktadır.

Rusya'nın siyasi üstünlüğüne karşı, Çin'in ekonomik ve de uzun vadeli projelere ağırlık vermesi ŞiÖ’nün bölgedeki rolünü daimi kılan unsurlardan bir diğeridir. Sınırdaş olmanın sunduğu ticari koridor konumu ve doğrudan enerji güzergâhlarının inşa edilebilirliği, Orta Asya ülkelerine bağımsızlı̆̆n ilk fırsatını, iktisadi bağımsızlı̆g 1 vermiştir. İlgili projeler Şı̈Ö kapsamında gerçekleştirilmiş olmasa dahi, özellikle enerji satışında Rusya'nın tekelci politikasından tavize varmasında, karşıdaki ülkenin Çin olmasının ve mevcut örgütsel işbirliğinin etkisi büyüktür. Kazakistan petrol üretiminin dörtte birini gerçekleştirmekle ve Türkmenistan doğal gazının yüzde 70'ini tüketmekle Çin, bölge ülkelerindeki rejim güvenliğinin en önemli kaynağı olan enerji satışında Rusya'nın "Gazprom” şirketini dengelemektedir (Butiya, 2019).

Ayrıca, üzerinde görüşmelerin devam ettiği ve çevre ülkelerin hemen hepsini kapsamasının planlandığ 1 "Ekonomik Kuşak" ve "21. yüzyılın Deniz İpek Yolu”, kısaca "Tek Yol, Tek Kuşak" stratejisini ortaya atmakla Çin, bölgede Rusya'yı dengeler konuma geldiğini bir kez daha belli etmiş̧tir. 2009 yılında devreye giren ve Rusya'nın bölgedeki enerji tekelinin kırılması olarak algılanan Orta Asya Doğalgaz Boru Hattı; mevcut Kazakistan-Çin Petrol Boru Hattı'nın yanı sıra Kazakistan ve Çin sınırında "Khorgos" Lojistik Merkezi'nin kurulması ile gerçekleştirilen Özel Ekonomik Bölge Planı (Frolovskiy, 2016); 2016 yılında Özbekistan'da Angren-Pap demiryolu tünelinin hizmete girmesiyle başlayan ve Özbekistan-Kırgızistan-Çin demiryolu hattının inşasıyla devam eden (Koparkar, 2017) “Tek Yol, Tek Kuşak" projeler dizisi, Çin'in Orta Asya'daki konumunu belirleyen misallerden birkaçıdır. Fakat yine ŞiÖ gibi mevcut işbirliği tecrübesiyle Rusya ile Çin bu konuda müzakereler yapmakta, "İpek Yolu Ekonomik Kuşağı ve AEB" adı altında birleşerek karşılıklı dengeyi sağlamaya çalışmaktadırlar. Söz konusu projelerin başarılı olması durumunda, ŞiÖ siyaset ve güvenlik ağırlıklı dengeleyici rolünü devam ettireceği gibi, Orta Asya'da AEB'yi dengeleyecek bir kuşak daha çekilmiş olacaktır.

Güvenliğin öne çıktığı bir proje olan ŞıOÖ'de, Çin ve Rusya ile sınırdaş olmak Orta Asya'ya ayrı bir önem kazandırırken, bu sınırların Doğu Türkistan ile paylaş11ıyor olması söz konusu önemi daha da arttırmaktadır. Dolayısıyla bu iki büyük gücün bölgedeki statükodan yana olmalarının ve mevcut siyasi rejimlere destek vermelerinin sebebi sadece "otoriter dayanışma"dan ibaret değildir. Bu tür desteklerin başlıca sebeplerinden biri de bölge devletlerindeki rejim değişiminin İslamcı radikallerin iktidara gelmesi ile 
sonuçlanacağı tedirginliğidir (Rumer vd., 2007, s. 84). Lakin bu konuda dikkat edilmesi gereken, bölge içerisindeki radikalizm oranının, bölge dışından gelecek tehdit ihtimaline göre düşük olduğudur. Söz konusu bölge dışı etkenlere bakıldığında ise, Orta Asya ülkelerinin güvenlik arayışına Çin ile Rusya'nın ortak olma sebeplerinden bir diğeri, yani NATO ve AGIT'i dengeleme sebebi ortaya çıkmaktadır.

Lakin söz konusu dengeleme politikasını, özellikle ŞïÖ açısından, Batı karşıtı bir kutuplaşma olarak değerlendirmek muayyen gerçeklere uymamaktadır. Zira bölgedeki diğer projelere nazaran ŞïÖ’de, farklı siyasi sistemler veya devletler arasındaki işbirliği ön planda olup, taraflar arasında tek bir ideolojinin kurulması gibi bir amaç güdülmemektedir (Aris, 2011, s. 38). Ayrıca Hindistan ve Pakistan'ın örgüte üyeliği ve İran'ın muhtemel üyeliği, Şı̈Ö'nün dengeleyici etkisini arttırmanın yanı sıra, Batı karşıtı bir blok olduğu imajını zayıflatmaktadır. Örneğin, Hindistan'ın Özbekistan'daki eski büyük elçisi Skand Tayal, Rusya ile Çin'in Batı karşıtı veya Amerika karşııtı tavırlarına karşı, Hindistan'ın daha dengeli bir politika izlemesi ve ŞiÖ kapsamında varılan kararların diğer büyük güçler ile olan ilişkilere yönelik olumsuz tesirlerini önlemesi gerektiğini dile getirmiştir (“Great. Eur.”, 2016).

Şi̇O’nün sözü edilen büyük devletleri kapsayacak şekilde genişlemesinin Orta Asya ülkelerinin denge arayışına yeni istikametler açacağı malumdur. Diğer yandan, bu tür genişleme sonucu bölge devletlerinin örgüt kararları üzerinde yetki kaybına uğrayacağı ve mevcut büyük devletlerin belirlediği yoldan yürümeye mecbur kalacağı görüşleri de dile getirilmektedir (Pannier, 2015). Lakin, jeopolitik konumu ve mevcut enerji kaynaklarıyla Orta Asya bölgesi, söz konusu güçlerin çıkar alanı, dolayısıyla ortak buluşma noktası olma ehemmiyetine de sahiptir. Çin başta olmak üzere bölge devletlerinin tek bir aktör olarak hareket etmelerine olumlu bakmazsalar da, iki taraflı ilişkilerde bölge ülkeleriyle iyi geçinme ihtiyacı sabit kalacaktır.

\subsubsection{Büyük Oyun'un Bir Devamı Olarak “Büyük Orta Asya” Projesi}

19.yüzyılda Rusya ve İngiltere İmparatorlukları arasında Merkezi Avrasya'nın kontrolü üzerine doğan rekabetin jeopolitik adlandırılışı olarak Büyük Oyun, günümüzde $\mathrm{ABD}$, Çin, Rusya ve diğer büyümekte olan güçlerin de dahil olduğu geniş bir çerçevede cereyan etmektedir. Zamanla neo-neo şeklinde yenilenen söz konusu rekabetin, Merkezi Avrasya'nın bir parçası olan Orta Asya bölgesindeki devamı ise 'Büyük Orta Asya' projesi olarak kavramsallaştırılmaktadır. Yeni İpek Yolu ve C5+1 girişimleriyle de desteklenen bu projenin bölgedeki diğer projelerden farkı, belli bir kurumsal yapı altına alınmış olmamakla birlikte, bakıldığı istikamet noktasına (Rusya, ABD vs.) göre farklı yönlerden açılanmasıdır. ABD tarafından ortaya atılmış olup Orta Asya ülkelerinin Afganistan, Pakistan ve Hindistan ile işbirliği içerisinde büyük bir aktör konumuna geleceğini öngören bu projede, bölge dışı paradigmalar ağır bassa da, proje kapsamında geliştirilen enstrümanlar Orta Asya'daki bağımsızlık arayışına yeni istikametler sunmaktadır.

Büyük Oyun'un bir devamı olarak günümüz Büyük Orta Asya projesinin tarihi geçmişi 19.yüzyıla kadar uzansa da, projenin kavramsal boyutu ve yürürlük enstrümanları ile birlikte uygulamaya konulması SSCB'nin dağılış yıllarına denk gelmektedir. Projeye Orta Asya odaklı bakıldığında, bu bölge üzerinde cereyan eden Büyük Oyun'u üç aşamaya ayrımak mümkündür. Bağımsızlıkların elde edildiği ilk yıllarda Orta Asya bölgesi ABD’nin Rusya'ya yönelik dış politikasının bir alt dalı olarak gündeme alınmıştır. Daha sonra, dönemin dışişleri bakan yardımcısı Strobe Talbott'un öne sürdüğü: "Birleşik Devletler'in Orta Asya'ya yönelik herhangi bir çıkarı bulunmamaktadır. Büyük Oyun ise geçmişin bir eseridir. Bizim amacımız bölgeye hakim olmak değil, başkalarının hakimiyetine veya hakimiyet adına girilen rekabete engel olmaktır. Orta Asya bölgesi, sahip olduğu doğal kaynakları işleterek iktisadi istikrara kavuşmalı, büyük bir serbest bölge (great-power-free zone) konumuna gelmelidir" (Rumer vd., 2007, ss. 30-31) teklifi, iddia edilenin tersine yeni bir Büyük Oyun'u başlatan sebeplerden biri olmuştur.

Rusya ve Avrasya araştırmacısı Eugene Rumer, Talbott teklifinin kabul görmeyişinde dış aktörlerin yanı sıra Orta Asya ülkelerinin de önemli rol oynadığını belirtmektedir. Ona göre bölge ülkeleri, Rusya, Çin, İran ve Afganistan gibi aktörler ile sınırdaş olmalarından dolayı tek bir bölgesel aktör olarak bekalarını korumaları gerekirken, oksimoron bir dayanışma sergilemiş, komşularına karşı çıkarlar güderek birbirinin güçlenmesini önlemişlerdir. Bu durumda Rusya, Çin ve ABD arasındaki rekabet bölge ülkeleri tarafindan arzulanan bir gelişme haline gelmiş̧ir. Neticede, bölgedeki komşuluk ilişkisi gelişememiş, ülkeler ise dış yardıma bağlı kalmıştır (Rumer vd., 2007).

11 Eylül 2001 olayları nezdinde yenilenen Büyük Oyun'un ikinci aşaması, ABD asker güçlerinin Orta Asya’ya girdiği ve Putin iktidarının başlaması ile Rusya'nın Orta Asya'ya döndüğü döneme denk 
gelmektedir. Güvenlik amacıyla girip Rusya'nın bıraktığı siyasi boşluğu da doldurmayı veya bölge üzerinde yetki paylaşımını amaçlayan ABD'nin, toparlanan Rusya'yı ve büyüyen Çin'i karşısında bulmasıyla söz konusu ikinci aşamanın başladığını söylemek mümkündür. Çünkü Rumer'in belirttiği gibi Orta Asya'da güvenliğin sağlanması aynı zamanda ekonominin modernleştirilmesi ve bölge devletlerinin entegre edilmesi gibi iktisadi ve politik kaynakları da gerektirecekti. Bu durumda $A B D$, kendi müttefikleri ile birlikte demokratik değerlerin ve iktisadi özgürlüğün savunulduğu "fikir savaşı"nı kazanmalıydı (Rumer vd., ss. 4344).

Orta Asya devletlerinin bu ikinci aşamadan aldıkları ibretler ise, ABD ile Rusya arasında geliş-gidiş manevrası yapmak ve gerektiğinde bu iki gücü Çin ile dengelemekten ibaret olmuştur. Ayrıca söz konusu manevraların bedelini Kırgızistan'daki Lale Devrimi ve Özbekistan'daki Andijan Olayları ile ödetmek isteyen ABD stratejisi, bölge ülkelerine dış yardımlara karşı tedbirli davranma dersini de vermiştir.

Bir müddet aradan sonra ABD'nin Orta Asya'ya attığı bir sonraki adım ise, "Büyük Orta Asya Stratejisi” adını almakla Büyük Oyun'un üçüncü aşamasını oluşturmaktadır. Frederick Starr'ın önderliğinde ortaya atılan Büyük Orta Asya Stratejisi, bölgedeki Rus ve Çin etkisini, büyük güç makamına aday olan Hindistan ve Pakistan aracılığıyla dengelemeyi amaçlamaktadır. Afganistan'ın da dahil olduğu "Büyük Orta Asya"'y1, enerji ve ticaret güzergâhıyla Güney Asya'ya bağlamakla tüm bölgenin yeniden doğuşunu sağlama rolünü de Washington üstlenmektedir (Starr, 2008, Akt: Tian, 2009 s. 68) Pakistan ile Hindistan'1 projeye dahil etmekle Büyük Orta Asya Stratejisi, ŞïÖ'nün bölgedeki genişleme hareketlerini de dengeler gözükmektedir. Söz konusu iki ülkenin ŞiÖ’ye üyelik çalışmalarının yürütüldüğü süreçte Amerika Birleşik Devletleri'nin Türkmenistan-Afganistan-Pakistan-Hindistan doğal gaz hattının inşası ile ilgili projeye destek vermesi buna bir örnektir (Starr, s.69).

Büyük Orta Asya Stratejisi kapsamında geliştirilen projelerin bir diğeri de, 2011 yılında Clinton tarafından dile getirilen "Yeni İpek Yolu" projesidir. Afganistan ve Orta Asya'nın gelişmesi ve bölge ülkelerinin Batı ile doğrudan temasa geçebilmeleri açısından Pakistan ile Hindistan'ın önemli rol oynayacağı iddiasıyla başlatılan bu proje, Çin ve Rusya işbirliğinde başlatılan İpek Yolu Ekonomik Kuşağı ve AEB projesine karşı bir alternatif sunmaktadır. Pakistan ile Hindistan'ın Orta Asya'ya yönelik stratejilerinin, ŞİÖ'ye üye olmadan da gerçekleşebileceği fikrini öne süren Yeni İpek Yolu projesinde Afganistan merkez olarak bellenmektedir. İpek Yolu'nun ABD tarafından çizilen yeni güzergâhında, Kırgızistan-TacikistanAfganstan- Pakistan istikametli CASA-1000 elektrik aktarma ve ticaret projesi ile TürkmenistanÖzbekistan-Tacikistan-Afganistan-Pakistan istikametli TUTAP bölgesel elektrik marketi projesi önde gelenlerdendir ("The New Silk Road", 2015).

Eylül 2015 Birleşmiş Milletler (BM) Genel Kurulu genel görüşmeleri sırasında ABD Dışişleri Bakanı John Kerry'nin bölgedeki beş devletin dışişleri bakanlarıyla bir araya gelmesi ile başlayıp, Kerry'nin Orta Asya turu ile devam eden (Tolipov, 2015) ve Büyük Orta Asya stratejisini bir kez daha gündeme taşıan projelerin bir diğeri de $\mathrm{C} 5+1$ formatında diyalog projesidir. Söz konusu diyalog sırasında, daha önceki projelerde devamlı dile getirilen terörizm, uyuşturucu satışı, güvenlik, demokratik reformlar ve insan haklarıyla ilgili meselelerden ziyade, ülkelerin iktisadi rekabet gücü, bölgesel ticaret, iklim ve Aral Denizi sorununun akıbetleri, su sorununun yönetilmesi, eğitim ve mesleksel değişimler ve kültürel miras gibi konulara ağırlık verilmiştir (Tolipov, 2015). Tüm bu gelişmelere bakıldığında, ABD önderliğindeki projelerde de, bölge ülkelerinin rejim güvenliği ve siyasi bağımsızlık konusundaki hassasiyetlerinin dikkate alındığını ve ülkelerin dış denge arayışına hitap edecek inisiyatiflerin sunulduğunu görmek mümkündür.

\subsubsection{Türk Konseyi: TÜRKSOY Uluslararası Türk Kültürü Teşkilatı ve TÜRKPA}

Rusya'nın Orta Asya'daki ‘büyük ağabey'lik hırsına karşı 'ağabey' demeniz yeterlidir diyen, fakat Rus Avrasyacılığı'nı Türk usulü Avrasyacılık ile dengeleme stratejisine sahip Türkiye önderliğindeki projeler, ortak tarih, dil ve kültür paylaşımından kaynaklanmaktadır. Türk Dili Konuşan Ülkeler İşbirliği Konseyi ve bu kapsamda geliştirilen Türk Dili Konuşan Ülkeler Parlamenter Asamblesi (TÜRKPA) ve TÜRKSOY Uluslararası Türk Kültürü Teşkilatı projeleri, Rus, Çin ve Batı rekabeti karşısında bölge ülkelerine bir alternatif istikamet daha sunmaktadır. Ayrıca siyasi amacın baskın olmaması ve bölge ülkelerinin tümünü birden kapsamamakla beraber diğer bölgelerdeki, özellikle Rusya'daki Türk halklarına da hitap etmesi, söz konusu projelere esneklik kazandırmakta, istikrarlı bir faaliyet alanı sağlamaktadır. 
SSCB'nin dağılmasıyla ortaya çıkan yeni Türk devletlerine "örnek ülke” (Veliyev, 2014) olarak giriş yapan Türkiye Cumhuriyeti'nin teşviki ve çok yönlü işbirliğinin daimi taraftarı Nursultan Nazarbayev'in de teklifine atfen kurulan Türk Konseyi'nin temeli, 1992 yılından bu yana düzenlenen "Türk Dili Konuşan Ülkeler Devlet Başkanları Zirveleri" ile atılmıştır. Türk Dili Konuşan Ülkeler arasındaki dayanışmanın arttırılması ve yeni işbirliği imkanlarının yaratılmasını amaçlayan Türk Konseyi tarafından desteklenen işbirliği projelerinin siyasi ve ekonomik ucunu 21 Kasım 2008 tarihinden bu yana TÜRKPA tutarken, 1993 'ten bugüne kardeş ülkeler arasındaki sosyal ve kültürel ilişkileri pekiştime girişimleriyle TÜRKSOY, daha fonksiyonel ve gözle görülür bir hızla ilerlemektedir (“Ort. As. İlişk.”, 2016) .

Ayrıca, bölge ülkelerinin Türk Konseyi, TÜRKPA ve TÜRKSOY kapsamında varılan ortak çalışmalara katılım düzeyi de söz konusu projelerin faaliyet alanlarının genişliğini belirlemektedir. Örneğin, Türk devletleri olmalarına rağmen Türkmenistan ile Özbekistan'ın Türk Konseyi ve TÜRKPA'ya taraf olmamaları, kurumların işbirliği alanlarından kaynaklanan politik sebeplere işaret ederken, tarihsel ve kültürel bağımsızlığa hitap etmekle TÜRKSOY, Orta Asya Türk devletlerinin yanı sıra Rusya Federasyonu içerisindeki Türk cumhuriyetlerini ve Gagavuzya, Kuzey Kıbrıs Türk Cumhuriyetini de kapsayacak geniş bir faaliyet alanı bulabilmiştir.

İlişkilerin sosyal ve kültürel boyutunun öne çıkmasında işbirliğine taraf olan ülkelerin yanı sıra dış aktörler de önemli rol oynamaktadır. Orta Asya ülkeleri ve bu ülkelerin işbirliğine taraf oluş şekli söz konusu iç ve diş etkenleri ortaya serecek en iyi örneklerdendir. Her şeyden önce, Orta Asya ülkelerinin bağımsızlık ve siyasi rejim güvenliğini koruyacak denge arayışında, jeopolitik sınırlarıyla bölgeyi çevreleyen Rusya-Çin ve Afganistan aracılığıyla bölge merkezine gelip konan ABD gibi güçler karşısında, Türkiye'nin ayrı bir istikamet bellenmesini gerektiren en makul sebep, tarih, kültür ve dil bağıdır. Bundan dolayıdır ki, Türkiye'yi söz konusu büyük güçlerle birlikte siyasi ve ekonomik dengeleyici sıfatında görmek bölge ülkeleri açısından daha az verimli olacaktır. Zira, sözü edilen güçler arasında aranan jeopolitik ve ekonomik denge, bölge ülkelerine has kültürel değerleri çiğneyebilecek durumdayken, siyasi bağımsızlıkların ulusal ve tarihi esaslara dayandırılarak muhafaza edilmesinde aranan, belki de tek dengeleyici aktör Türkiye'dir.

Gerçekte de, aradaki coğrafi mesafe ve bu mesafenin Rusya ve Çin gibi büyük güçlerin 'yakın çevre'sinden geçiyor olmasına rağmen Türkiye ile Orta Asya ülkelerini işbirliğine yönelten en makul sebep ortak tarih ve kültür ilişkisidir. Bu durumda söz konusu işbirliğini pekiştirecek en makul yöntem de kültürel diplomasidir. TÜRKSOY Genel Sekreter Yardımcısı Fırat Purtaş'ın da belirttiği gibi kültürel diplomasi sayesinde, toplumlar arasında tanışıklık arttırılmakta ve güven tesis edilmektedir. Karşıllıklı güven ise, devletler arasındaki siyasi ve ekonomik işbirliğinin bir ön koşulu sayılmaktadır (Purtaş, 2013). Bu varsayımdan hareketle, Türk Konseyi ve TÜRKSOY'un desteğiyle gerçekleştirilmekte olan kültürel projelerin (Türk Dünyasının Kültürel Merkezi İnisiyatifi, Nevruz kutlamaları ve Türk Kültür ve Miras Vakfı vb.), Türkmenistan ve Özbekistan'ın da dahil olduğu siyasi ve ekonomik ortaklığa, dolayisıyla Hazar Denizi'nin köprü olacağı Orta Asya-Azerbaycan-Türkiye bölgesel işbirliğine yol açacağını öngörmek mümkündür.

Nihayetinde, Türkiye Büyük Millet Meclisi Başkanı İsmail Kahraman'ın: "Birlikten kuvvet doğar. Yan yana geleceğiz, daima birlik olacağız. Gelişmemizi istemeyen, ayağa kalktıkça önümüzü kesmek isteyen bir başka dünya var. Birlik ve beraberliğimizin önündeki engelleri tarihten gelen köklerimizin birliğiyle aşacağız" (Dünya Bülteni HP, 12.2016) şeklindeki konuşması örnek alınırsa, Orta Asya devletlerinin çok yönlü bağımsızlık arayışında, Rusya, Çin ve ABD gibi bölgeye kök salmış dengeleyiciler karşısında Türkiye'yi bulmaları, yine tarihsel ve kültürel işbirliği ile mümkün olacaktır.

\subsection{Orta Asya'da Bağımsızlıkları Koruyacak Güç Dengesi Arayışının Kuramsal ve Uygulamalı Değerlendirilmesi}

Uluslararası ilişkiler literatüründe Orta Asya devletlerinin taraf olduğu işbirliği projeleri, ağırlıklı olarak neoliberal kurumsalcılık ve sosyal yapısalcılık veya neorealizm ve güç dengesi yaklaşımları olmak üzere iki ayrı açıdan değerlendirilmektedir. Yaklaşımların ilk grubu bölgesel örgütler, onların işlevleri ve devletlerarası işbirliği üzerindeki etkilerinden yola çıkarken, ikinci grup bölgenin jeopolitik özellikleri ve bölge etrafındaki dış güçlerin bölgesel işbirliğine katılım düzeyine ağırlık vermektedir (Krasnopolsky, 2013). Söz konusu gruplaştırma üzerinden değerlendirildiğinde, bu çalışmanın kuramsal boyutu ikinci grubu tamamlayıcı niteliktedir. Çünkü, Rusya, Çin ve $\mathrm{ABD}$ başta olmak üzere küresel güçlerin buluşma noktası 
olan, ilişkilerin devlet merkezli yürütüldügü ve rejim güvenliği ile özdeşmiş olan siyasi bağımsızlığın, güçler arası denge arayışıyla pekiştirildiği bir bölge olmasından ötürü Orta Asya'yı en iyi realist okul -klasik realizm, neorealizm ve güç dengesi- tanımlayacaktır. Bölgedeki denge arayışının bir mekanizması olarak işbirliği projelerini ve bu projelerin bağımsızlık üzerindeki işlevini ise işlevselcilik yaklaşımı nezdinde değerlendirmek mümkündür.

Uluslararası sistemde dengeleyici rol oynayan ve dolayısıyla sistemdeki büyük güçler tarafından geliştirilen yapılar olarak görülse de, günümüz devletlerarası işbirliği projeleri büyük devletlerin olduğu kadar zayıf devletlerin de birtakım çıkarlarını korur durumundadır. Orta Asya ülkelerinin taraf olduğu işbirliği projeleri de Rusya-Çin, Rusya-Batı veya Batı-Doğu arasındaki stratejik rekabet ağırlıklı ele alınmakta, lakin söz konusu rekabet dahil olmak üzere bu projeler bölge ülkelerinin bağımsız aktör olarak kimliklerini muhafaza etmelerinde önemli rol oynamaktadır. Özellikle yeni elde edilen bağımsızlıkları bölgesel bir işbirliği kurumuyla paylaşmaya razı gelmeyen genç devletler için, bölge dışı güçlerle olan çok yönlü işbirliği daha avantajlı bulunmaktadır.

Bölge devletlerinin güç dengesini sağlayacak işbirliğinden yana olmalarında, ilgili devletlerin bağımsızlık kazanma sürecinin de tesiri büyüktür. Çünkü yeni bağımsız olan ülkelerin özellikle siyasi bağımsızlık konusunda yaşadıkları hassasiyetlerin büyük bir kısmı, daha önce tabi oldukları yönetim sistemine, bu sistemden ayrılma sebebine ve yine aynı yönetim sisteminin bağımsızlık sonrası politikasına göre şekil almaktadır. Bu bakımdan, SSCB dönemindeki merkezi sistemin etkisi, daha sonra bu etkinin Rusya tarafından devam ettirilec ĕgi endişesi, Orta Asya ülkelerini kendi aralarında entegrasyon oluşturmanın yanı sıra birden fazla büyük güç ile işbirliği içine girme çabasına düşürmüştür. Devlet egemenliğini inşa etme girişimleriyle aynı anda yürütülen entegrasyon ve işbirliği ilişkilerinde, dış aktörler ile ilişkilerin bölgesel entegrasyonu geride bırakmasındaki temel sebeplerin başında da geçmişteki yönetim bağlılığ 1 ve yetersiz devlet tecrübesi yer almaktadır.

Bağımsızlığın bölge dışı ilişkilerde aranmasının bölge kaynaklı sebeplerinden bir diğeri de ülkelerin sahip oldukları kalkınma kapasiteleri ve avantajları arasındaki farklılıklar ve bölgesel sorunların çözümü ile ilgili görüş ayrılı̆̆ıdır. Bu durum aynı zamanda Orta Asya'da meydana gelen işbirliği girişimlerinin, sadece Rusya, Çin, ABD, AB ve diğer uluslararası aktörlerin, aralarındaki rekabetten kaynaklanan tek taraflı jeostratejik denge arayışının bir sonucu olmadığını göstermektedir. Çünkü, her devletin kendi imkanlarını bölge devletlerinden bağımsız ve dış güçler ile temas içerisinde geliştirme politikası, dış güçlerin de bölgeye yönelik stratejik denge arayışına yol hazırlamıştır.

Orta Asya ülkelerinin birbirinden bağımsız olarak büyüme azmi realist kuramın devlet merkezli ulusal çıkar anlayışına (Morgenthau, 2006) dayandırılabilmektedir. Lakin, bölge ülkelerinin sahip olduğu sınırlı avantajlar dolaysıyla buradaki ulusal çıkar, etken bir güçten ziyade tepki veya korunma maksatlı yumuşak gücü amaçlamaktadır. Egemen devlet bekasını güvence altına alacak olan yumuşak gücün önemli bir kısmı da, yine neorealist okulun ittifak formülü (Bkz. Waltz, 1988) aracıllğıyla edinilmektedir. Bölge açısından söz konusu yumuşak güçler arası güvenlik ikileminin devletler bazında olmaktan çok örgütler arasında cereyan ettiği de varsayıldığında, Rusya, Çin, Batı ülkeleri ve diğer eksen devletlerle varılan projeler (BDT, AEB, ŞİÖ, Büyük Orta Asya, Yeni İpek Yolu, C5+1, TÜRKPA, TÜRKSOY vb.) olmak üzere ikileme taraf olan aktörler ortaya çıkmaktadır.

Askeri manevralardan ziyade siyasi-ekonomik ittifaklara ve yumuşak güce dayalı olması sebebiyle Orta Asya'daki örgütsel güvenlik ikilemlerini, realist yaklaşımın diğer bir dalı olan güç dengesi kuramı (Morgenthau, 2006) kapsamında da değerlendirmek mümkündür. Çünkü, bölge ülkelerinin birkaç rakip güç ile aynı anda işbirliği yapma eğilimini güç dengesi kuramındaki 'denge've 'dengeleyici' kavramları en iyi açıklamaktadır. Bu açıdan Rusya ile ABD ve taraftarlarınca ortaya atılan projeler (BDT, AEB - Büyük Orta Asya, C5+1) birbirlerini dengeler durumdayken, Batı karşıtı olarak görülmesine rağmen Çin, ne daimi dostu, ne de daimi düşmanı olan dengeleyici aktör rolünü üstlenebilmektedir.

Ayrıca, bölge ülkelerinin dış politikalarında ortak özellik olarak bilinen ve çoğu zaman Rusya'nın bölgedeki hegemon gücünü dengeleme amaçlı algılanan Çin ve ABD destekli projeler, realist okulun bandwagoning stratejisi ile de açıklanabilmektedir. Zayıf devletlerin siyasi destek başta olmak üzere muayyen avantajlar elde etmek için büyük devletlerin yanında yer aldığ 1 varsayımına dayanan bandwagoning stratejisine (Paul vd., 2004) göre, Orta Asya ülkeleri devlet egemenliğini zedeleyebilecek 
tehditlere karşı uluslararası sistemin en büyük güçleri arasında yer değiştirmektedirler. Buradaki tehdidin niteliğine göre, Rusya'nın güvenlik, iktisadi veya ticari sınırlamalarına karşı Çin ve Batı destekli projelere imza atılırken, siyasi rejim güvenliği ve dış politika alanında Rus rejiminin desteğine ihtiyaç duyulmaktadır. Kazakistan ile Türkmenistan söz konusu stratejiyi dengeli devam ettirmeye çalışırken, Özbekistan, Kırgızistan ve Tacikistan'da bandwagoning istikametinin değişimi kolay izlenebilmektedir.

Özbekistan'ın KGAÖ ve NATO arasındaki manevraları veya Kırgızistan'ın devrim ile değişen dış politika uygulamaları gibi siyasi bandwagoning değişimi, ilgili ülkelerin uluslararası işbirliği karşısındaki önemini de belirlemektedir. İşbirliğine taraf devletler arasında görülen güce dayalı rol farklılı̆̆ı söz konusu manevralar sebebiyle daha da büyüyebilmektedir. Orta Asya siyaset uzmanı Farkhot Tolipov'un da belirttiği gibi, dış güçler ile devam eden bu tür ilişkiler bölge devletleri açısından bir 'işbirliği'nden ziyade boyun eğme veya 'itaat' anlamına gelmektedir. Söz konusu itaat ilişkisinin işbirliğine dönüştürülmesi ise, ilk önce bölge ülkelerinin kendi aralarındaki işbirliğini gerektirmektedir (Tolipov, 2010, s. 108).

Orta Asya hükümetleri açısından bölge dışı güçler ile olan işbirliğinin ideolojik boyutunu açıklamakta Morgenthau'nun ideolojik dayanışma varsayımdan faydalanmak mümkündür. Söz konusu varsayıma göre benzer özelliklere sahip devletler birbirlerine karşı tehdit oluşturmamaktadırlar. Bu durum aynı zamanda işbirliği içerisindeki zayıf bir rejimin kendi meşruluğunu devam ettirmesine de kolaylık sağlamaktadır (Walt, 1985, ss. 4-5). Bu açıdan, geçmişteki komünist ideolojiden kalma günümüz otoriter sistem dayanışması bölge ülkelerini Rusya ile işbirliğine yöneltirken, ulusal bağımsızlık sonrası geliştirilen ortak köken, ortak kültür ideolojisi de Türkiye- Orta Asya dayanışmasına yol hazırlamıştır.

İlişkilere proje veya örgüt merkezli bakıldığında, Orta Asya ülkelerinin taraf olduğu çok yönlü işbirliği girişimlerini neofonksiyonalizmin 'spill over' varsayımı en iyi betimlemektedir. Bu varsayıma göre belli bir sektörde gerçekleştirilen işbirliği, ilgili alandaki diğer sektörleri de işbirliğine götürecektir. Lindberg tarafından daha kapsamlı bir tanıma ve dolayısıyla geniş bir uygulama alanına kavuşan spill over formülünde ise, özel bir amaca yönelik yapılan muayyen faaliyet, asıl amaca ulaşmak için yeni bir faaliyeti daha gerektirmektedir. Aynı durum ilerde daha yeni faaliyetler türetmekte, bu zincir devam etmektedir (Heinonen, 2006, s. 57). Bu halde, kuruluş amacı güvenlik olup daha sonra iktisadi ve politik alanlara yayılan ŞïÖ ve KGAÖ kapsamındaki girişimleri veya AEB ve Tek Yol Tek Kuşak İpek Yolu Projesi gibi ekonomik projelerin siyasi kutuplaşmaya götürdüğü iddialarını spill over stratejisi olarak ayrı bir başlık altında araştırmak mümkündür.

Ayrıca, Lindberg'in siyasi işbirliğinin herhangi bir siyasi topluluk kurulmaksızın da yürütülebileceği varsayımı (Heinonen, s. 56) fonksiyonalizmin Orta Asya'yı açılama gücünü bir adım daha arttırmaktadır. Varsayımın, hükümet temsilcileri arasında yapılacak olan kolektif karar alma yoluyla varılan ve devletlerin egemen aktör konumlarının muhafaza edildiği bir siyasi işbirliğini daha uygulanabilir bulması, bölge ülkelerinin dış güçler ile olan iki taraflı ilişkilerini analiz etmede yardımcı olmaktadır. Zira muayyen politikaların desteklenmediği veya beklenen çıkarların karşılanmadığı durumlarda ikili işbirliğinden vazgeçmek, kurumsal bir projeden çekilmekten daha kolay gerçekleşmektedir. Bu durumda devletler kısa zaman içerisinde başka bir işbirliğine imza atabilmekte, veya Özbekistan ve Türkmenistan misali kendi içerisinde kapalı bir bütünleşmeye yönelmektedirler.

Son olarak, Orta Asya'daki bağımsızlık arayışında dış güçlerle olan projelerin tercih edilme sebebi olarak dış yardım faktörünü ve bu yardımlarla gelen lobi faaliyetlerini göz ardı etmemek gerekmektedir. Ekonomik, sosyal veya güvenlik alanlarında sağlanan dış yardımlar, başlangıçta bağımsız bir amaçmış gibi tanıtılmakta, beklenen siyasi sürecin başlatılmasıyla da politik lobi faaliyetlerinde araç olarak kullanılmaktadır. Bu tür baskı politikaları aracılığıyla büyük güçlerin, bölge devletlerinin bağımsız karar alma yetkisini sınırladıkları, dolayısıyla devletlerarası işbirliği projelerinde de küçük devletlerin egemenlik haklarının çiğnendiği görüşü (Walt, 1985, ss. 30-31) Orta Asya ülkeleri açısından da söz konusudur. Lakin, bölge ülkelerinin taraf olduğu mevcut işbirliği projelerinin tek bir güç ile değil, birbirleriyle rekabet içerisinde olan birkaç güç ile yapılmış olması ve bu gidişatla oluşan çoklu bir çerçeve, ülke bağımsızlıklarının da çok yönlü muhafaza edilmesini sağlamaktadır.

\section{Sonuç}

Soğuk Savaş sonucu ait oldukları kutbun dağılmasıyla bağımsızlık statüsünü elde eden Orta Asya devletleri, bağımsız aktör statüsünü pekiştirmede hem galip gelen kutup üyelerinden muayyen tecrübeler 
edinmeye, hem de idari bağ içerisinde oldukları ülkeler ile ortak meseleleri çözmeye ihtiyaç duymuşlardır. Geçmişteki yönetim tarzı ile ona karşı gelen değerlerin harmanlanmasını gerektiren çok yönlü işbirliği, bölgeyi kendi etki alanına katmak isteyen güçler arasında dengeyi sağlayacak sayılı stratejilerden biriydi. Lakin söz konusu strateji yalnızca bölge ülkelerinin ihtiyaçları ile sınırlı olmayıp, işbirliğine taraf olacak dış güçlerin geniş çaplı jeopolitik hedefleri ile de doğrudan bağlantılı olduğu için yapılan işbirliği projelerinde bölge dışı ilişkiler ağırlık kazanmıştır. Ayrıca, ilk yıllarda arka arkaya imzalanan bölge içi işbirliği anlaşmalarına rağmen, devlet inşa süreci boyunca ülkelerin kalkınma firsatlarında meydana gelen farklılıklar ve bu kalkınmaya engel oluşturacağı endişesi yaratan ortak kaynaklar üzerindeki tartışmalar bölge devletlerini birbirinden uzaklaştırmıştır.

$\mathrm{Bu}$ gidişatla her ülkenin yönetim sistemi bölgedeki diğer devletlerden ayrı bir örümcek ağı şeklinde gelişmiş, ağın kılavuz ipi de devletin kurucu atası olarak liderlerin eline geçmiştir. Tek liderliğin meşruiyet kaynağı olarak siyasi rejim güvenliği ise sağlam inşa edilmiş ülke bağımsızlığına dayanmaktadır. Bu durumda, kendi bağımsızlıklarını henüz pekiştirememiş bölge ülkeleri arasındaki dayanışma, dış güçlerin sağlayacağı hazır 'koruyucu işbirliği' karşısında zayıf kalmıştır. Bunun en önemli sebeplerinden biri ise bölge devletlerinin tarihi devlet ve meşruiyet tecrübesinin zayıflığı olmuştur. Söz konusu tecrübeyi paylaşırken Rusya'nın bölgeyi yeniden kendi etki alanına alacağı endişesi, bölge ülkelerini Batı dünyası ve Çin ile işbirliğine yöneltirken, Türkiye, İran, Hindistan ve diğer eksen ülkeler olmak üzere bölgeye ilgi gösteren aktör sayısındaki artış, Orta Asya açısından işbirliği alanını gittikçe genişletmiştir.

Uluslararası sistemde, Orta Asya ülkeleri gibi ortak bir bölgeyi temsil eden devletlerin, işbirliği ilişklerini bölgesel entegrasyon nezdinde yürüttükleri görülmektedir. Ulus üstü kurum karşısında egemenlik haklarından ciddi tavizlere varan $\mathrm{AB}$ ülkeleri ve kendi aralarında egemenlik paylaşımı olmazsa dahi dış güçlere karşı bölgesel düzeyde direniş gösteren Latin Amerika ve Güney Afrika devletleri arasındaki işbirliği projeleri mevcut eksikliklere rağmen bu konuda misal olmaya şayandırlar. Orta Asya topraklarına bu gözle bakıldığında, bağımsızlık konusunda karşl1ıklı ödünlerden ziyade, bölge ülkelerinin bugüne kadar imza attıkları bölge dışı güçler ile olan işbirliği projeleri öne çıkmaktadır. Bağımsızlıktan bugüne bölgesel meselelerin ortak çözümü, ortak mesuliyet ve diş dünyaya karşı ortak tavır izleme ile ilgili pek çok bilimsel öneri ve projeler dile getirilmiştir. Dolayısıyla, bu çalışmada öne sürülecek öneriler son yıllarda bölge içerisinde meydana gelen değişimler üzerinden yapılandırılacaktır.

Orta Asya'nın tek bir bölgesel aktör olarak bütünleşmesi veya dış güçler arasında bölünmesi açısından Özbekistan'ın bugüne kadar oynadığı rol büyüktür. Kazakistan ile birlikte bölgenin en etkin ülkesi olan ve Orta Asya algısının hem başlangıcı, hem de merkezi olarak Özbekistan, bölgedeki Rusya-Batı veya BatıDoğu ikileminde en çok rol alan bir ülkedir. Bundan dolayıdır ki, bölgesel işbirliğini devamlı dile getiren Kazakistan ve bu konuda Kazakistan'1 devamlı destekleyen Kırgızistan ile Özbekistan'ın yeni yönetimi arasında bölgesel işbirliği görüşmelerinin yeniden başlatılması ortak bölgesel imajın oluşturulması açısından yıllardır beklenen bir adım olacaktır.

Daha önce de belirtildiği gibi, Kırgızistan haricinde bölgedeki her lider aynı zamanda bir ulus babasıdır. Liderler arası ilişkiler çoğu kez devletlerarası ilişkileri belirler niteliktedir. Dolayısıyla ülkesinin kendi tanıttı̆̆ imaj çerçevesinde algılandığı ve yürüttüğü rejim politikasının desteklendiği bir işbirliği, liderlerin 'devlet' konumunu meşrulaştıracaktır. Böyle bir durumda, yeni atanan lider en az bir öncekisi kadar başarılı olmak isteyecek, onun tamamlayamadığ1 meseleleri tamamlayacak, yeni politikalar ortaya atacaktır. Özbekistan lider değişimi ile başlayan ve diğer Orta Asya ülkeleri için de söz konusu olan bu siyasi sürecin, bölgesel işbirliğine yönelik çalışmalarla değerlendirilmesi, bölgesel birlikteliğin temelini sağlamlaştıracaktır.

Her ne kadar birbirine zıt sorumluluklar doğurmuş ve bölge ülkeleri arasındaki mesafeyi arttırmış olsa dahi, birden fazla dış güçler ile varılan işbirliği projelerinden verimli sonuç çıkarmak, siyasi ibret edinmek mümkündür. Her şeye rağmen, bugüne kadar izlenen güç dengesi arayışı, Orta Asya'yı tek bir gücün nüfuzu altında kalma tehlikesinden uzaklaştırmış, bağımsızlıkları çok yönlü dış politika nezdinde devam ettirme tecrübesi kazandırmıştır. Artık her ülke siyasi ve idari mesuliyet yüklenme deneyimine sahiptir ve bu deneyim bölgedeki ortak sorunların çözülmesinde ve Orta Asya'nın tek bir bölgesel aktör olarak birleşmesinde faydasını gösterecektir. Bu bağlamda, emperyalist geçmişin mirası ve günümüzdeki jeopolitik rekabetin araçları olan etnik, sınır ve sınır aşırı su sorunları gibi ortak meseleleri, dış güçlerin elinde araç olmaktan çıkartılması, bölgesel işbirliğinin pekiştirilmesi Orta Asya Birliği açısından bir zarurettir. 


\section{Kaynaklar}

"НАКАНУНЕ Саммита ШОС-Китай, Центральная Азия, Россия: Как и Кем Будет Формироваться Большая Евразия?", [On the Eve of the SCO-China Summit, Central Asia, Russia: How and Who will Form the Great Eurasia?], (Haziran, 2016), Central Asian Analytical Network. Web: http://caanetwork.org/archives/7288 (Erişim: 24.06.2016).

ALLISON, Roy, (June, 2008). "Virtual Regionalism, Regional Structures and Regime Security in Central Asia", Central Asian Survey, 27(2), s.185-202. Web: http://www.tandfonline.com/page/terms-andconditions (Erişim: 22.01.2013).

ARIS, Stephen, (2011). Eurasian Regionalism: The Shanghai Cooperation Organization, Great Britain: Palgrave Macmillan.

BAĞIMSIZ Devletler Topluluğu Tüzüğü, Madde 12. BDT İnternet Portalı. Web: http://e-cis.info/ (Erişim: 22.05.2016).

BEST, Edward and Thomas Christiansen, (2014). "Regionalism in International Affairs", In John Baylis, Steve Smith, and Patricia Owens (Eds.), The Globalization of World Politics: An Introduction to International Relations, (Sixth edition), UK: Oxford University Press.

BRZEZINSKI, Zbigniew and Paige Sullivan, (Eds.) (1997). Russia and the Commonwealth of Independent States: Documents, Data and Analysis, New York: The Center for Strategic and International Studies and M.E. Sharpe.

BRZEZINSKI, Zbigniew, (1998). The Grand Chessboard: American Primacy and Its Geostrategic Imperatives, New York: Basic Books.

BUTIYA, Sam, (9 October, 2019). Магистраль Туркменистана в Китай [Turkmenistan's Highway to China], Eurasianet.

Web:https://russian.eurasianet.org/\%D0\%BC\%D0\%B0\%D0\%B3\%D0\%B8\%D1\%81\%D1\%82\%D1\%80\% D0\%B0\%D0\%BB\%D1\%8C-

$\% \mathrm{D} 1 \% 82 \% \mathrm{D} 1 \% 83 \% \mathrm{D} 1 \% 80 \% \mathrm{D} 0 \% \mathrm{BA} \% \mathrm{D} 0 \% \mathrm{BC} \% \mathrm{D} 0 \% \mathrm{~B} 5 \% \mathrm{D} 0 \% \mathrm{BD} \% \mathrm{D} 0 \% \mathrm{~B} 8 \% \mathrm{D} 1 \% 81 \% \mathrm{D} 1 \% 82 \% \mathrm{D} 0$ \%B0\%D0\%BD\%D0\%B0-\%D0\%B2-\%D0\%BA\%D0\%B8\%D1\%82\%D0\%B0\%D0\%B9 (Erişim: 10.12.2019).

CHINA-Central Asia Gas Pipeline Transports 47.9 Billion Cubic Meters in 2019, (7 January, 2020), Hellenic Shipping News. Web: https://www.hellenicshippingnews.com/china-central-asia-gas-pipeline-transports-479-billion-cubic-meters-in-2019/(Erişim: 30.01.2020).

CHINA-Kazakhstan Oil Pipeline Transports 10.88 mln Tonnes in 2019, (10 January, 2020), Hellenic Shipping News. Web: https://www.hellenicshippingnews.com/china-kazakhstan-oil-pipeline-transports-1088-mln-tonnes-in-2019/ (Erişim: 15.02.2020).

CUMMINGS, Sally N., (Ed.) (2002). Power and Change in Central Asia, New York: Routledge.

DADABAEV, Timur, (April, 2007). "Central Asian Regional Integration: Between Reality and the Myth", Central Asia-Caucasus Analyst, 9(9), s.6-9. Web: http://www.cacianalyst.org/ (Erişim: 15.02.2016).

DUTKIEWICZ, Piotr and Richard Sakwa, (Eds.) (2015). Eurasian Integration: The View From Within, New York: Routledge. 
FROLOVSKIY, Dmitriy, (July, 2016). "Kazakhstan's China Choice”, The Diplomat. Web: http://thediplomat.com/2016/07/kazakhstans-china-choice/ (Erişim: 25.05.2016).

HEINONEN, Hannu, (2006). Regional Integration and the State: The Changing Nature of Sovereignty in Southern Africa and Europe, Helsinki: IDS.

KARIMOV, İslam, (2011). Узбекистан на Пороге Достижения Независимости, [Uzbekistan on the Threshold of Independence], Taşkent.

KELLY-Clark, Victoria, (May, 2016). "Why Central Asia is dumping Russia for China?" Global Risk Insights. Web: http://globalriskinsights.com/2016/05/why-central-asia-is-dumping-russia-for-china (Erişim: 25.12.2016).

KOPARKAR, Rashmini, (February, 2017). "25 Years of Uzbekistan-China Relations: Enhanced Economic Engagements Marked by Political Understanding", Vivekananda International Foundation. Web: http://www.vifindia.org/article/2017/february/16/25-years-of-uzbekistan-china-relations-enhancedeconomic-engagements-marked-by-political-understanding (Erişim: 21.03.2017).

KRASNOPOLSKY, Peter, (2013). "Major Powers and Regionalism in Central Asia" International Studies Association.

Web: http://web.isanet.org/Web/Conferences/GSCIS\%20Singapore\%202015/Archive/8e26ebb3-f4a34a13-ac59-adb0ee445aa5.pdf (Erişim:22.09.2016).

LAUMULIN, Murat, (2011). "Central Asia and Pax Iranica: Cooperation and Interdependence", Central Asia and Caucasus, 12(2), s.109-126. Web: http://cyberleninka.ru/article/n/central-asia-and-pax-iranicacooperation-and-interdependence (Erişim:15.02.2016).

LEUNG, Michael, (2007). "Forum Report: Does Japan Matter in Central Asia?" Central Asia-Caucasus Analyst, 9 (9), s.19-20. Web: http://www.cacianalyst.org/ (Erişim: 15.02.2016).

MITRANY, David, (1948). "The Functional Approach to World Organization”, International Affairs, 24 (3), s.350-363. Web: http://www.lsu.edu/faculty/lray2/teaching/7971_1s2009/mitrany1948.pdf(Erişim: 19.01.2016).

MON, Christian O., (May, 2016). "The EU and Member States Sovereignty", AALEP. Web: http://www.aalep.eu/eu-and-member-states-sovereignty (Erişim: 10.04.2016).

MORAVCSIK, Andrew, (1994). "Why the European Union Strengthens the State: Domestic Politics and International Cooperation", Center for European Studies, Harvard University, Çalışma no.52, s.7-14. Web: http://aei.pitt.edu/9151/1/Moravcsik52.pdf (Erişim: 24.04.2016).

MORGENTHAU, Hans, (2006). Politics among Nations the Struggle for Power and Peace, (Seventh edition), New York: Mc Graw-Hill.

NAZARBAYEV, Nursultan, (1997). Евразийский Союз: Идеи, Практика, Перспективы, [Eurasian Union: Ideas, Practice, Prospects], Moskova.

NAZARBAYEV, Nursultan, (2003). Стратегия Независимости, [A Strategy for Independence], Almat1.

NURGALIYEV, Marat and Timur Shaymergenov, (2007). "Japanese Diplomacy Makes New Headway in Central Asia: Its Problems, Expectations and Prospects", Central Asia and Caucasus, 6 (48), s.125-135. Web: http://cyberleninka.ru/article/n/japanese-diplomacy-makes-new-headway-in-central-asia-its-problemsexpectations-and-prospects (Erişim: 15.02.2016).

OLCOTT, Marta B., (1998). "Central Asia: Confronting Independence”, The James A. Baker Institute for Public Policy of Rice University. Web: 
http://www.bakerinstitute.org/media/files/Research/133113ba/central-asia-confronting-independence.pdf (Erişim: 15.02.2016).

ORTA Asya Ülkeleri ile İlişkiler, T.C. Dısişleri Bakanlı̆̆ı. Web: http://www.mfa.gov.tr/turkiye-orta-asyaulkeleri-iliskileri.tr.mfa (Erişim: 26.12.2016).

PANNIER, Bruce, (July, 2015). "Are The Central Asians The Losers in SCO Expansion?" RadioFreeEurope/RadioLiberty. Web: http://www.rferl.org/a/central-asia-sco-expansion-/27134212.html (Erişim: 25.05.2015).

PAUL, Thazha, James Wirtz and Michel Fortmann, (Eds.) (2004). Balance of Power: Theory and Practice in the 21st Century, California: Stanford University Press.

PURTAŞ, Fırat, (Aralık, 2013). "Kültürel Diplomasi ve TÜRKSOY”, Medeniyet ve Kültür Araştırmaları Merkezi. Web: http://mekam.org/mekam/kulturel-diplomasi-ve-turksoy (Erişim: 25.12.2016).

RASOV, Sergey, (11 Eylül, 2012). “Против Кого Дружат Каримов и Назарбаев?”, [A Frindship between Karimov and Nazarbayev is Against Whom?], Respublika-kz. Web: http://www.respublikakz.info/news/politics/25192 (Erişim: 03.01.2015).

RUMER, Eugene, Dmitri Trenin and Huasheng Zhao (2007). Central Asia: Views from Washington, Moscow and Beijing, New York: M.E. Sharpe, Inc.

RUSYA'DAN Orta Asya ile İşbirliği Açılaması, (29 Nisan, 2016), Dünya Bülteni. Web: http://www.dunyabulteni.net/orta-asya/362621/rusyadan-orta-asya-ile-isbirligi-aciklamasi (Erişim: 30.04.2016).

SERİKPAYEV, Damir, (12 Eylül, 2019). “Что значит Китай для Казахстана? Цифры и факты”, [What does China mean for Kazakhstan? Numbers and Facts], Forbes Kazakhstan. Web: https://forbes.kz//process/expertise/chto znachit kitay dlya kazahstana? (Erişim: 29.11.2019).

SIMONOV, Eugene, (7 November, 2019). "Half of China's Investment in Kazakhstan Is in Oil and Gas", The Third Pole. Web: https://www.thethirdpole.net/en/2019/11/07/half-of-chinas-investment-in-kazakhstanis-in-oil-and-gas/ (Erişim: 21.12.2019).

THE New Silk Road: A Path to Regional Security?, (December, 2015), Eurasian Council on Foreign Affairs, 8. Web: http://ecfaenglish.objects.dreamhost.com/wp-content/uploads/2015/12/ECFA-Occasional-PaperThe-New-Silk-Road-A-Path-to-Regional-Security_rev-.pdf?dm_i=25TR,3X9GE,FNWMR4,E57TY,1 (Erişim: 06.08.2016).

TIAN, Robert G., (2009). "From Central Asia to Great Central Asia: The Goals and Adjustments of U.S. Central Asian Strategy", Central Asia and the Caucasus, 3(57), s.58-71. Web: http://www.cac.org/journal/2009-03-eng/05.shtml (Erişim: 06.08.2016).

TOLIPOV, Farkhod, (February, 2010). "Geopolitical Stipulation of Central Asian Integration”, Strategic Analysis, 34(1), s.104-113. Web: http://www.tandfonline.com/doi/abs/10.1080/09700160903378319 (Erişim: 06.04.2015).

TOLIPOV, Farkhod, (November, 2015). "Pluses and Minuses of the C5+1 Format" The CACI Analyst. Web: http://cacianalyst.org/publications/analytical-articles/item/13300-pluses-and-minuses-of-the-c5\%201format.html (Erişim: 06.08.2016).

TROYITSKIY, Evgeniy, (2013). “Политика Индии в Центральной Азии 2001-2012”, [India’s Central Asian Policy 2001-2012], Вестник Томского Государственного Университета, No: 375, s.106-108. Web: http://cyberleninka.ru/article/n/politika-indii-v-tsentralnoy-azii-2001-2012-gg (Erişim: 15.02.2016).

TÜRK Dili Konuşan Ülkeler Parlamenter Asamblesi’nin Yeni Binası Açıldı, (Aralık, 2016), Dünya Bülteni Haber Portall. Web: http://www.dunyabulteni.net/gunun-haberleri/388609/turk-dili-konusan-ulkelerparlamenter-asamblesinin-yeni-binasi-acildi (Erişim: 23.12.2016). 
VELIYEV, Cavid, (July, 2014). "The Role of Turkic Council for the Future of Eurasian Politics", Eurasia Daily Monitor. 11 (124). Web: https://jamestown.org/program/the-role-of-the-turkic-council-for-the-futureof-eurasian-politics/ (Erişim: 25.12.2016).

VINOKUROV, Evgeniy, (2007). Теория Анклавов, [A Theory of Enclaves], Kaliningrad: Terra Baltika.

WALT, Stephen M., (Spring, 1985). "Alliance Formation and the Balance of World Power", International Security, 9 (4), s.3-43. Web: http://links.jstor.org (Erişim: 15.02.2016).

WALTZ, Kenneth, (1988). “The Origins of War in Neorealist Theory", Journal of Interdisciplinary History, 18 (4). Web: http://www.columbia.edu/itc/sipa/S6800/courseworks/OriginsOfWar.pdf(Erişim: 15.02.2016).

ЖИРИНОВСКИЙ Оскорбил Страны Центральной Азии, Предложив Объединить Их в Федеральный Округ, [Jirinovsky Has Insulted Countries of Central Asia, By Proposing Unite Them in the Federal District], (Şubat, 2014), NEWSru. Web: http://palm.newsru.com/russia/26feb2014/zhirinovsky.html (Erişim: 24.05.2016).

ОБЪЕМ Китайских Инвестиций в Таджикистан Превысил \$2 млрд., [Chinese Investment in Tajikistan Exceeds \$2 Billion], (18 June, 2019), Avesta Information Agency. Web: http://avesta.tj/2019/06/18/obemkitajskih-investitsij-v-tadzhikistan-prevysil-2-mlrd/ (Erişim: 30.12.2019).

ЦЕНТРАЛЬНО-Азиатское Сотрудничество объединяется с Евразийским Сообществом, [Central Asian Cooperation Unites with the Eurasian Community], (Ekim, 2005), ИО REGNUM. Web: https://regnum.ru/news/524490.html (Erişim: 22.05.2016).

ЭКСПЕРТЫ: Кто и Как Сформирует Большую Евразию? [Experts: Who and How Will Form a Greater Eurasia?], (Haziran, 2016), Fergana Haber Portall. Web: http://www.fergananews.com/articles/9005 (Erişim: 24.06.2016). 